\title{
STUDIES ON BRITISH LAMINARIACEAE. I. GROWTH IN LAMINARIA SACCHARINA (L.) LAMOUR.
}

\author{
By Mary Parke, B.Sc., Ph.D.
}

Botanist at the Plymouth Laboratory

(Plates V-XIII and Text-figs. I-IO)

\section{CONTENTS}

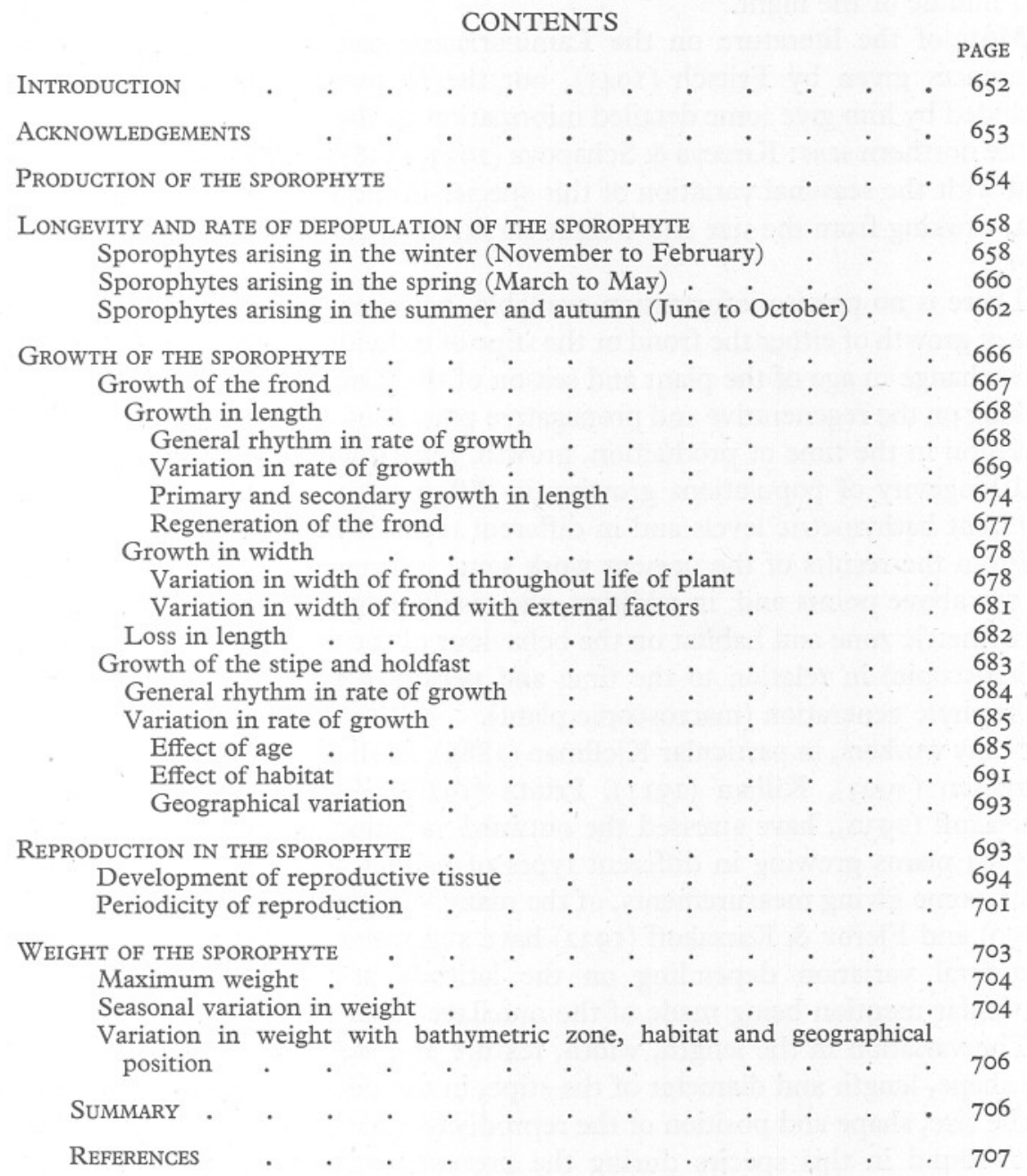




\section{INTRODUCTION}

Very little information was available at the beginning of the Second World War on the growth and behaviour of the common British Fucaceae and Laminariaceae when a need for this knowledge arose for economic purposes. An investigation was started, therefore, on these groups at the request of, at first, a private firm, Messrs Cefoil Ltd., and later the Ministry of Supply.

This first paper deals with Laminaria saccharina (L.) Lamour. and gives the results of observations made from I94I to I945 on the south coast of Devon, in the neighbourhood of Plymouth, and on the coast of Argyll, off the island of Luing. At both places low water of spring tides occurs in the middle of the day and middle of the night.

Most of the literature on the Laminariaceae can be obtained from the references given by Fritsch (1945), but the following Russian papers not included by him give some detailed information on the growth of $L$. saccharina in the northern seas: Kireeva \& Schapova (1933, I938) and Tikhovskaya (1940) deal with the seasonal variation of this species in the Kola Fjord and Barents Sea, working from the size and weight variation of the species throughout the year.

There is no precise information available, however, on the variation in the rate of growth of either the frond or the stipe of individual plants of this species with change in age of the plant and season of the year. Precise information is lacking on the regenerative and propagative powers of this species; also on the variation in the time of production, growth, reproduction, depopulation rate, and longevity of populations growing in different geographical positions, at different bathymetric levels and in different types of habitat.

From the results of the present work some information has been obtained on the above points and, in addition, the results have shown the influence of bathymetric zone and habitat on the behaviour of the gametophyte generation (microscopic) in relation to the time and period of production by it of the sporophyte generation (macroscopic plant).

Many workers, in particular Kjellman (I883), Foslie (I890), Setchell (I900), Børgesen (I903), Killian (I9II), Printz (I926), Zinova (I929), Flerov \& Karsakoff (1932), have stressed the outward variation in the form of $L$. saccharina plants growing in different types of habitat and have given descriptions, some giving measurements, of the many varieties of this species. Foslie (I890) and Flerov \& Karsakoff (I932) have suggested also a possible internal structural variation depending on the latitude at which growth occurs, particular mention being made of the mucilage canal system of the frond.

The variation in the length, width, texture and bullations of the frond, in the shape, length and diameter of the stipe, in the design of the holdfast, and in the size, shape and position of the reproductive tissue on the frond that has been found in this species during the present work can be related to the 
variation in the rate of growth with changes in age, season, habitat and geographical position (Pls. V-VIII). Not only can growth forms of L. saccharina be classed as varieties of the species, some of the forms obtained agree even with the descriptions of distinct species. For instance, second-year plants in very exposed habitats in the intertidal zone agree with Agardh's (I867) description of $L$. hieroglyphica, whilst summer-developed plants at the northern station, in the late spring and summer of the following year, in sheltered habitats in the sublittoral zone, agree with Børgesen's (1903) description of $L$. faeroensis; this species with more rapid stipe growth would resemble L. longicruris De la Pylaie of the north-eastern coast of North America if Setchell (I900) is correct in stating that mucilage canals are absent from the stipe.

It would be of great systematic interest if the chromosome numbers were known and transplanting experiments from one latitude to another could be carried out on the following species of Laminaria: L. agardhii Kjellman, L. faeroensis Børgesen, L. groenlandica Rosenvinge, L. longicruris De la Pylaie, L. hieroglyphica J.Ag. and L. saccharina (L.) Lamour. Evidence could then be obtained to show whether they are really distinct species or all growth and latitude forms of the one species.

In this work three zones are distinguished on the shore, the intertidal, the sublittoral fringe and the sublittoral.

The intertidal zone is regarded as extending from extreme high water of spring tides down to just above low water of mean spring tides.

The sublittoral fringe zone is that zone distinguished by Stephenson (I937, I939) 'to designate the part of the sublittoral zone which extends above extreme low water of spring tides. The fringe remains submerged at low water of neap tides, its degree of emergence at low water of springs depending very much upon variations in wave action.' This zone extends above extreme low water of the lowest spring tides to approximately $0.1 \mathrm{~m}$. above low water of mean spring tides at the southern station and $0.5 \mathrm{~m}$. at the northern station.

The sublittoral zone is the region below extreme low water of spring tides in which the attached algae are permanently submerged.

\section{ACKNOWLEDGEMENTS}

Miss Emily Clay, B.Sc., assisted me in the shore work from February 1942 to September I945. I owe her a special debt of gratitude for her willing help at all times. Special thanks are due to Dr Margery Knight of Liverpool University for her stimulating interest throughout the course of the investigation. I am greatly indebted to the late Dr S. W. Kemp, F.R.S., who was Director of the Plymouth Laboratory when this investigation started, for his interest and encouragement during the earlier stages of the work. Special thanks are due to the present Director, Mr F. S. Russell, F.R.S., for his advice and warm encouragement during the later stages of the work. To Dr W. R. G. Atkins, 
F.R.S., my most grateful thanks are due for the reading and criticism of the manuscript. I am much indebted to $\mathrm{Mr} \mathrm{E}$. Ford for advice on statistical methods. I am greatly indebted to the late Dr E. J. Allen, F.R.S., and to Miss Mary Sexton for the translation of some of the more important references. My sincere thanks are due to the whole staff of the Plymouth Laboratory for help throughout the work, in particular to $\mathrm{Mr}$ F. J. Warren for suggesting the system of marking the frond by means of punched holes and for help with the shore work and the photography, and to Mr F. G. C. Ryder for designing special punches, labels, measuring apparatus and concrete blocks and also for help with the shore work and the photography. My thanks are due to Mr H. McLachlan of the Island of Luing, Argyll, for his help and great interest in the work.

The expenses of this investigation were covered by grants from the Development Fund, the Ministry of Supply and Messrs Cefoil, Ltd.

\section{PRODUCTION OF THE SPOROPHYTE}

Schreiber (1930) found that the gametophyte generation of $L$. saccharina growing in culture was perennial but was fertile only during the winter and spring; he attributed the loss of fertility during the summer to the increase in temperature. He found that fertility could be induced during the summer in strains of gametophytes, started during the winter and spring, growing at a temperature of $16-18^{\circ} \mathrm{C}$. by lowering the temperature to $6^{\circ} \mathrm{C}$. He therefore concluded that there was no inherent seasonal alternation of sterile and fertile periods, but that the power of gamete production was at all times released by the action of suitable external conditions quite independently of the time of the year. As he found young sporophytes in nature only in the spring he believed that, although the gametophyte could be perennial in nature, it was fertile only during the winter months.

The results obtained by Harries (1932) disagree with those of Schreiber, since she states that oogonia develop on female gametophytes in temperatures up to $16^{\circ} \mathrm{C}$. She does say, however, that when the temperature is raised above a certain degree it inhibits reproduction although it accelerates growth. She concludes from her experiments that, when there is a suitable light intensity and sufficient phosphate, fertility of the gametophyte varies with the nitrate concentration, but that when there is a sufficient quantity of nitrate and phosphate present in the medium then the fertility varies with the light intensity.

The present investigations have shown that sporophytes of $L$. saccharina can be produced in nature during all months of the year at some level on the shore, on both normal untouched areas and on experimental areas from which the original population had been removed. The gametophyte generation of this species must, therefore, be capable of reproduction during all months of the year. 
Table I. Production of the Sporophyte of LAMinaria SACCHARINA in Relation to Bathymetric Zone and Habitat

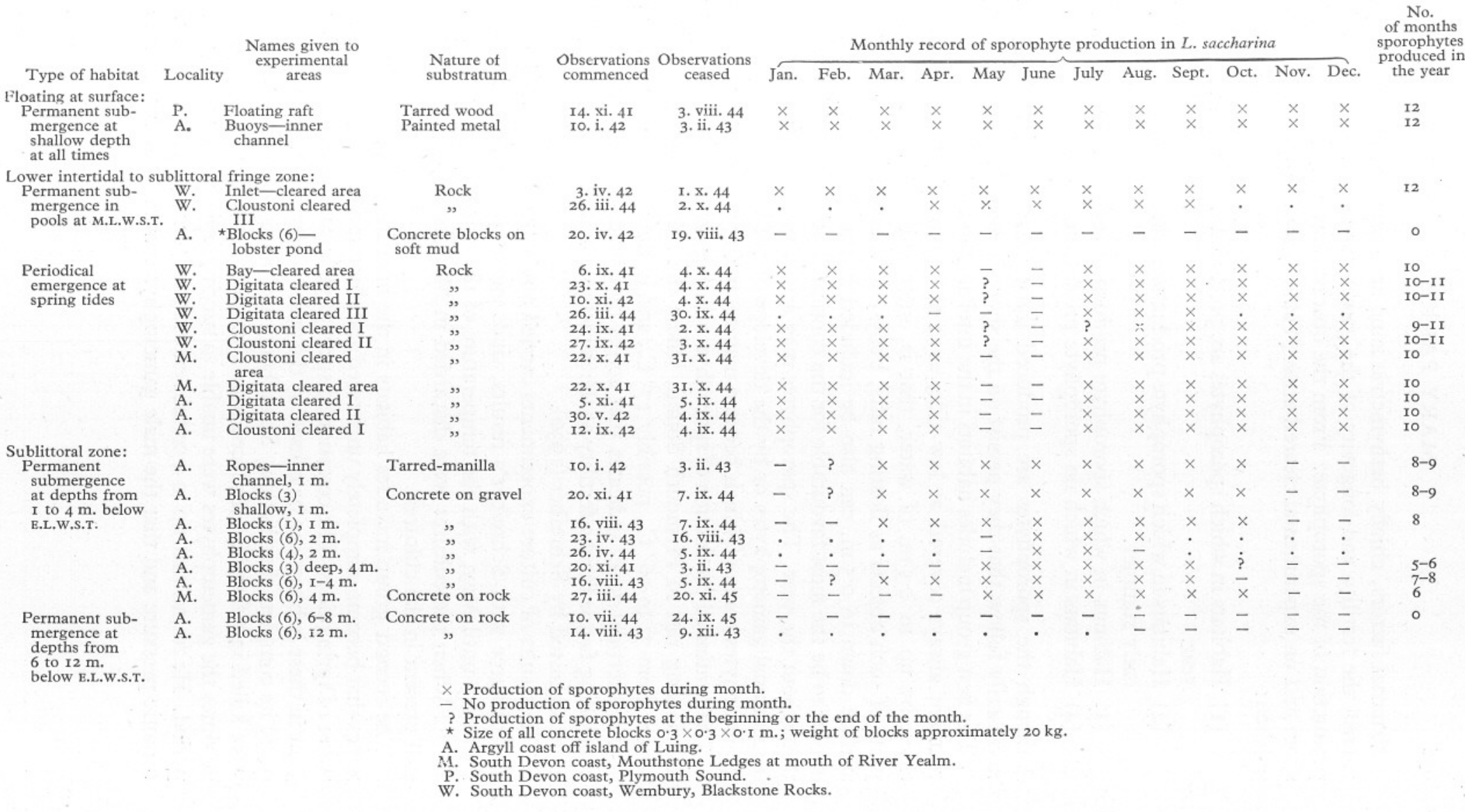


External factors, chiefly bathymetric zone and type of habitat, appear to control the fertility and longevity of the gametophyte and consequently the production of the sporophyte. From the observations on normal areas of the shore and on experimental cleared areas (Table I) four groups can be distinguished:

(I) Habitats in which sporophytes are produced during all months of the year.

(2) Habitats in which sporophyte production ceases in the late spring and early summer.

(3) Habitats in which sporophyte production ceases in the winter.

(4) Habitats in which no sporophyte production has been recorded.

Although the sporophytes are produced during these periods it does not necessarily follow that they persist on the shore beyond the sporeling stage.

The first group includes habitats in the intertidal and sublittoral fringe zones that are always covered at low tide, even at extreme low water of spring tides, by up to $0.5 \mathrm{~m}$. of water, that is, intertidal pools. The submerged parts of such objects as floating rafts, buoys, and ropes from just below the surface down to $0.5 \mathrm{~m}$. can also be included in this group. These habitats appear to be the most favourable for the continued production of sporophytes throughout the year. The sporophytes may arise from the persistent fertility of perennial gametophytes or by the development of successive crops of new gametophytes some of which become mature during all months of the year.

The continued production of sporophytes during every month of the year on the floating raft in Plymouth Sound, where the surface water temperature ranges from $7^{\circ}$ to $16^{\circ} \mathrm{C}$., possibly $17^{\circ} \mathrm{C}$., and in the pools on the lower part of the intertidal zone, indicates that actual temperature rise may not be the controlling factor for the fertility of the gametophyte under natural conditions as is suggested by Schreiber (1930).

The results of culture experiments carried out at the Plymouth Laboratory also disagree with Schreiber's results, since gametophytes were fertile from February until May, with the temperature of the cultures rising from $10^{\circ}$ to $19^{\circ} \mathrm{C}$. When the cultures were discarded in May fertile gametophytes were still present in the cultures.

The second group includes habitats in the intertidal and sublittoral fringe zones that become completely uncovered and dry out during the period of low water of spring tides. The cessation of sporophyte production during May and June in these habitats can be caused by the onset of sterility in the gametophyte or by its complete destruction. Schreiber (1930) found that the gametophytes were killed in a few days if placed near a window in summer light and that at all times the gametophytes were unable to survive drying out, even for a short period. He found that up to a certain extent they were insensitive to a rise in osmotic pressure and that the male gametophytes were more resistant to the 
rise in osmotic pressure than were the female gametophytes. So strongly developed was this character that the female gametophytes could be completely obliterated from a culture by slow evaporation so that the surviving plants were all male. In these habitats that dry out during low tide it seems more probable that the lack of sporophyte production during May and June is caused by the destruction of the gametophytes, perhaps only the female, during this period rather than by their sterility. This point, however, needs further investigation.

The third group includes habitats in the sublittoral zone $\mathrm{I}-4 \mathrm{~m}$. below E.L.W.S.T. The cessation of sporophyte development, possibly gametophyte development also, in these habitats from November to February, is most probably due to the low light intensities reaching these areas during the winter months. Atkins (1939) has shown, expressing the mean monthly daylight values as a percentage of the total for the year, that at Plymouth the lowest figures occur from November to January and that the six months, April to September, receive three-quarters to four-fifths of the annual daylight, an amount which increases with increasing latitude.

The proportion of light reaching the sublittoral experimental areas, compared with the full daylight reaching the floating raft in Plymouth Sound on which sporophytes develop during all months of the year, can be estimated roughly from the figures given by Atkins (I939, p. I48, Table I). Taking the extinction coefficient as 0.40 , an approximate value for blue light in turbid inshore waters, then approximately $45 \%$ only of the subsurface light is transmitted down to a depth of I-2 m., and only $14 \%$ or less to a depth of $5 \mathrm{~m}$. depending on the turbidity of the water in which a Secchi disc could be seen at rather more than $4 \mathrm{~m}$.

Sauvageau (I9I8) and Harries (I932) both agree that germination of the gametophyte can occur in the dark, but that a certain intensity of light is necessary for further growth and development. Harries also states that germlings developed in the dark can remain for some months capable of growth on being illuminated.

A fact suggestive also of the influence of the intensity of light is that young sporophytes are rarely found below a thick covering of the fronds of older plants. On some concrete blocks at a depth of I m. below E.L.W.S.T., for example, sporophytes, developed in the summer and autumn of 1942 and the spring of I943, had formed a thick covering over the blocks during the late spring and summer of 1943 . No new population developed during the summer of I943, but in the spring and summer of 1944 sporophyte development restarted on the blocks after the majority of the I 942 and early I943 populations had gone.

The fourth group includes habitats in the sublittoral zone 6-I2 m. below E.L.W.S.T. and also all habitats in all zones where the bottom is of soft mud. Although so far no development of young plants has been obtained on prepared surfaces at depths from 6 to I2 m., well-developed plants of L. saccharina have 
been brought up from depths down to $\mathrm{I} 2 \mathrm{~m}$. These plants, however, were all growing on shingle and may have been washed down into deeper water, having started their development in shallower water.

Habitats with a soft muddy substratum or prepared surfaces placed on soft mud appear to be quite useless for the production of sporophytes. This may be due to the continued sedimentation of the mud either cutting off the light, or smothering any possible gametophyte development, or forming a substratum from which the gametophytes are too easily removed.

Sporophyte production on the British coast can, therefore, be said to take place at the higher levels during the winter, early spring, late summer and autumn, and at the lower levels, down to a certain depth, during spring, summer and early autumn (Table I). In certain specialized types of habitats sporophyte production does not occur, and in others can take place throughout the whole year. In general, this species affords yet another example of algal migration up and down the shore first mentioned by Knight \& Parke (I93I), and since noted by other workers.

\section{LONGEVITY AND RATE OF DEPOPULATION OF THE SPOROPHYTE}

Throughout the period of sporophyte production at all levels and in all habitats a proportion, usually high, of the sporelings become detached from the substratum when they reach a length of from $I$ to $2 \mathrm{~cm}$. The variation in numbers of sporelings lost during the first month of growth and the longevity of the plants which survive the sporeling stage appear to be dependent on two factors, the time of the year at which germination of the plant occurs and the type of habitat in which it arises.

The data on the longevity and rate of depopulation of this species, taken from the records of populations that developed on experimental areas from I94I to I945, is summarized under three headings according to the time of germination of the sporophytes. Table II records the maximum ages, in months, reached by populations growing under different habitat conditions on the experimental areas.

\section{SPOROPHYTES ARISING IN THE WINTER (NOVEMBER to February)}

Winter sporophytes, produced only in the intertidal and sublittoral fringe zones, rarely survive beyond the sporeling stage unless the habitat is one of extreme shelter. The figures show that the loss of winter sporophytes during the first month of growth ranges from a $95 \%$ loss in sheltered habitats to a $100 \%$ loss in exposed habitats. The complete removal of winter sporophytes during the first month of growth takes place consistently year after year in all habitats with any degree of exposure, irrespective of whether the habitat dries out or remains covered by a shallow depth of water at low tide (Table II, nos. 2-6). 
Table II. Longevity of the Sporophyte of LAMINARIA SACChARINA In Relation to Time of Germination, BATHYMETRIC ZONE AND HaBitat

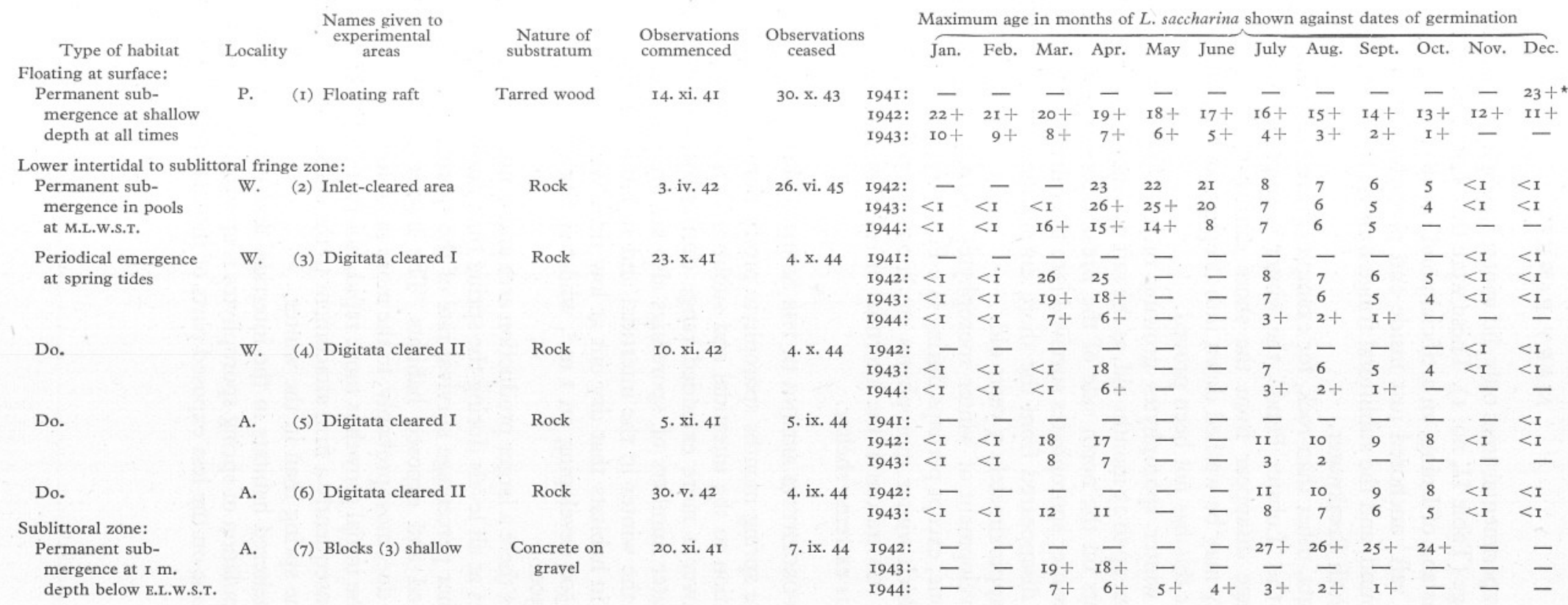

* + sign after a figure denotes that population still represented when observations ceased.

A. Argyll coast off island of Luing.

P. South Devon coast, Plymouth Sound.

W. South Devon coast, Wembury, Blackstone Rocks. 
On three experimental areas only did winter sporophytes survive beyond the sporeling stage (Table II, no. I). These were the 'Lobster Pond' off the west coast of the island of Luing, an artificial pond situated between small islands, the 'floating raft' anchored just inside and protected by the Breakwater in Plymouth Sound, and the sublittoral fringe zone on the north side (protected) of the Plymouth Breakwater.

On substrata, other than rock, for example, gravel mixed with small stones as found in the 'Lobster Pond', the winter sporophytes which survive the sporeling stage disappear from the shore during the first few months of growth. They may be washed down into deeper water where they survive to maturity, but this has not been proved.

Although winter sporophytes growing on the 'floating raft' had to be removed when up to 23 months old, as the raft was required for other purposes, labelled plants on the north side of the Breakwater showed that very small numbers of winter sporophytes survived into the third year of growth. These sporophytes disappeared from the shore during the fourth winter when the plants were approximately 3 years old.

As the development of winter sporophytes has not been recorded for the sublittoral zone, except perhaps during late February, the only type of natural habitat in which winter sporophytes are known to persist to maturity is one with a rocky substratum in the intertidal or sublittoral fringe zones on coasts where there is extreme shelter.

\section{SPOROPHYTES ARISING IN THE SPRING (MARCH to MAY)}

During the spring months sporophyte production occurs in the sublittoral zone in addition to the intertidal and sublittoral fringe zones, and therefore takes place over a more extended range during the spring than during the winter. Greater numbers of sporelings also are produced during the spring than during the winter in the intertidal and sublittoral fringe zones, except during May in habitats that dry out at low tide. Winter counts of sporelings give up to 2500 developing on I m. ${ }^{2}$, whilst spring counts of the sporelings give up to 5300 .

Not only is there a larger production area and a much greater fertility of the gametophytes at all levels during the spring than during the winter, but there is also a higher percentage survival rate of the sporeling stage at all levels in both sheltered and exposed habitats. The higher survival rate of spring sporelings is due, most probably, to the more rapid initial growth of the spring plants. As the initial growth is more rapid, holdfast development is also more rapid and consequently a firm attachment to the substratum is procured more quickly in the spring than in the winter.

In very sheltered habitats in the intertidal and sublittoral fringe zones the rate of depopulation of spring sporophytes is approximately the same as in the sublittoral zone on the less exposed parts of the coast. In these habitats from 
40 to $50 \%$ of the sporelings go from the substratum during the first 2 months of growth; a further $15-20 \%$ are lost from the second to the fourth month and another $5-10 \%$ from the fourth to the sixth month. Thus, by the time a population, growing under sheltered conditions, has reached 6 months old, $60-80 \%$ of the original population has been detached from the substratum. Loss in numbers continues throughout the life of a population, at I2 months old from 86 to $91 \%$ has been lost and at 24 months old from 98 to $99 \%$. At the end of 2 years, therefore, there is not more than $2 \%$ of the original population left on the shore to continue growth in the third year. Spring populations in the third year of growth can survive through the third summer, but they disappear during the third winter when the populations are nearly 3 years old.

On an exposed coast at all levels the rate of depopulation of the sporelings and of the young plants is more rapid. In habitats where there is any degree of exposure, from 60 to $65 \%$ of the sporelings become detached during the first 2 months of growth, a further $18-20 \%$ during the third and fourth months and another 7-10\% during the fifth and sixth months. On an exposed coast, therefore, a population 6 months old has lost from 85 to $95 \%$ of its original number, a loss which is $15-25 \%$ higher than on a more sheltered coast. By the twelfth month $94-97 \%$ of the population has gone, and during the next I2 months the remainder of the population may go in some habitats, but in others up to $0.7 \%$ may persist into the third year of growth. It is generally on intertidal and sublittoral fringe zone areas which dry out at low water of mean spring tides that plants do not survive beyond an age of 2 years (Table II, no. 3). In the sublittoral zone and in pools in the intertidal and sublittoral fringe zones the small percentage of a population that has survived up to 2 years, can live on through the third summer (Table II, no. 2), but goes from the substratum during the third winter when the population is nearly 3 years old.

The figures given above indicate that in all spring-developed populations of L. saccharina the largest number of plants, $86-97 \%$ of a population, become detached during the first year of growth. During the second year, however, the figures for the depopulation-rate of labelled plants shows that the heaviest losses of plants occur at different times of the year at different levels and in different types of habitats (Text-fig. I). In the intertidal and sublittoral fringe zone areas that dry out at low tide, although there is fairly heavy loss during the autumn and early winter months, the heaviest loss takes place during the spring - in May at the beginning of the second year, and during April and May at the beginning of the third year when all surviving plants succumb.

At the same levels, but in habitats which remain submerged at a shallow depth at low tide, there is some loss during the spring and the summer months; but the heaviest loss of second-year plants occurs during the autumn and early winter months (Text-fig. I B). In the sublittoral zone, even on sheltered coasts, heavy losses occur at two seasons of the year, during the 
summer from June to August and during the winter from December to February (Text-fig. IC).

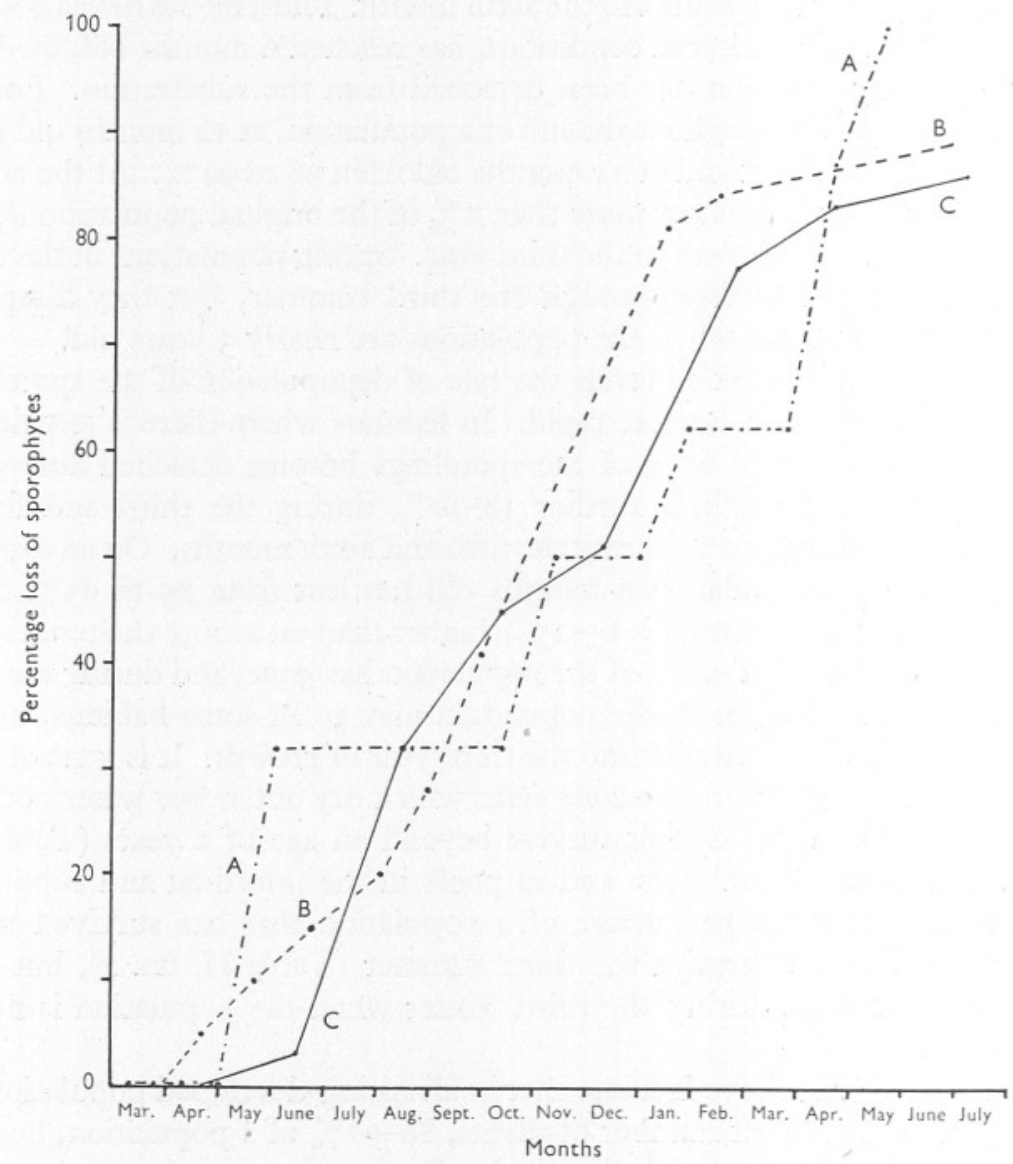

Text-fig. I. Depopulation in three spring populations of $L$. saccharina, growing in different habitats, from the $13^{\text {th }}$ to 27 th month of life. A, exposed shore, intertidal zone, above M.L.W.S.T. B, exposed shore, intertidal zone, at same level as above, but submerged in pools. c, sheltered shore, sublittoral zone, at a depth of $\mathrm{I}$ m. below E.L.w.S.T.

Spring sporophytes in all habitats, except perhaps in the sublittoral zone on very sheltered coasts, can be said to form, at all times of the year, the bulk of any $L$. saccharina population occurring on the shore, since they are more persistent in nearly all habitats than either the summer or the winter sporelings.

SPOROPHYTES ARISING IN THE Summer AND Autumn (JunE to OCtober)

The longevity of sporophytes produced during the summer and autumn is controlled mainly by the nature of the habitat in which development occurs. At all levels, on shores with any degree of exposure, summer and autumn 
sporophytes rarely survive beyond the first winter although equally large numbers are produced as during the spring (Table II, nos. 2, 3, 4). Spring sporophytes by October are more robust and more firmly attached to the substratum than are the summer and autumn sporophytes and consequently

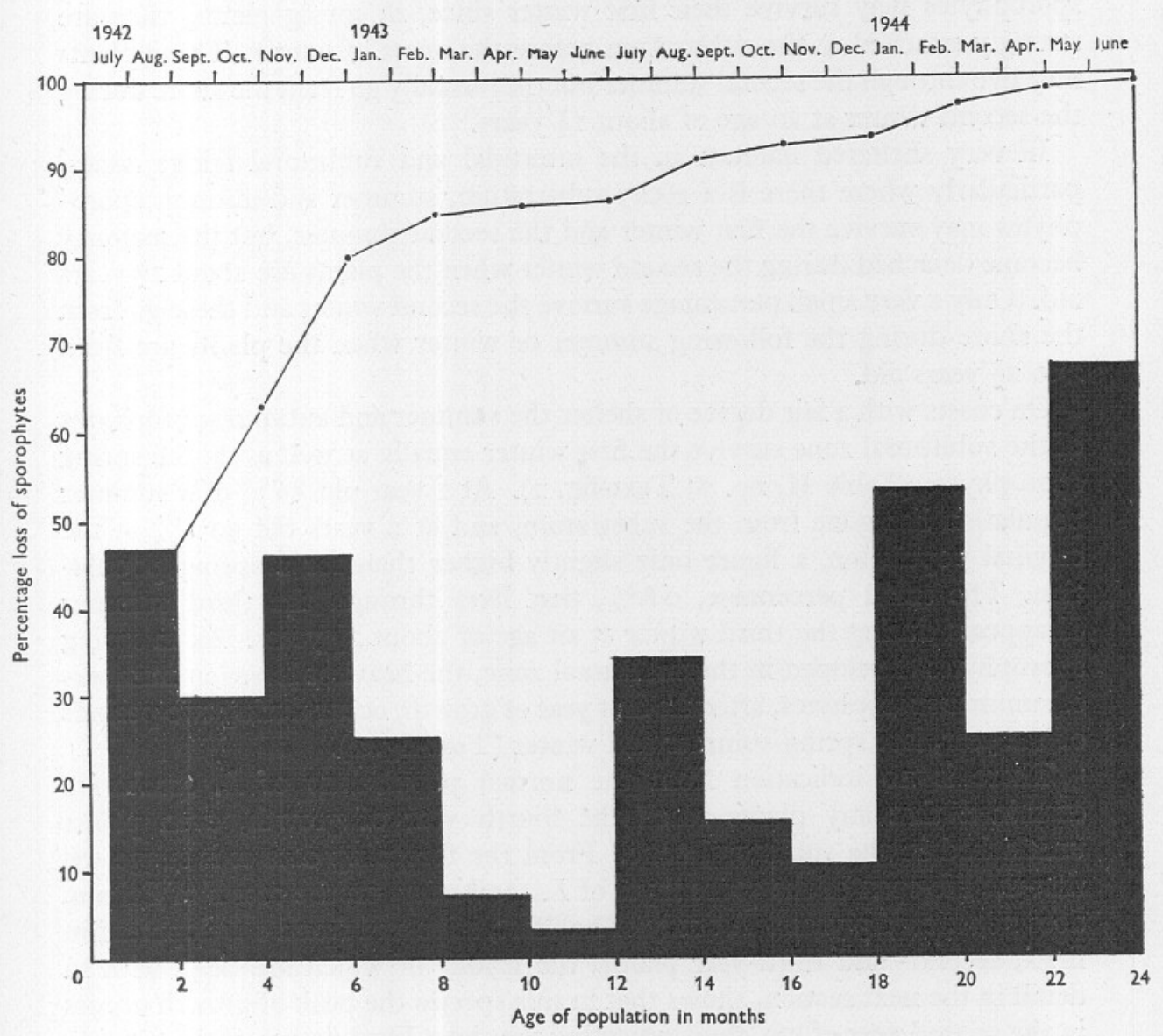

Text-fig. 2. Depopulation during the first 2 years of growth in a summer-developed population of $L$. saccharina, growing on a sheltered shore in the sublittoral zone at a depth of $\mathrm{I} \mathrm{m}$. below E.L.W.S.T. The upper curve gives progressive percentage loss throughout the 2-year period. Solid columns give percentage loss of the population present 2 months earlier.

stand a better chance of survival during the winter months than do the later developed plants.

The very small numbers of summer and autumn sporophytes that may survive the first winter in habitats which dry out at low tide disappear from the shore during the early part of the following summer before maturity has been reached (Table II, nos. 5, 6). The only summer sporophytes that may 
survive, in any number, into the second year in exposed habitats are those developed either in the sublittoral zone or on areas which remain covered by a shallow depth of water at low tide (Table II, no. 2). In these habitats, since no cessation of sporophyte production occurs during June, early summer sporophytes may survive their first winter since, as spring plants, they are strongly attached to the substratum before the onset of winter. These plants may live through the second summer but they usually go from the shore during the second winter at an age of about $\mathrm{I}_{2}^{\frac{1}{2}}$ years.

In very sheltered habitats in the intertidal and sublittoral fringe zones, particularly where there is a rocky substratum, summer and autumn sporophytes may survive the first winter and the second summer, but the majority become detached during the second winter when the plants are about $\mathrm{I} \frac{1}{2}$ years old. Only a very small percentage survive the second winter and these go from the shore during the following summer or winter when the plants are from 2 to $2 \frac{1}{2}$ years old.

On coasts with a fair degree of shelter the summer and autumn sporophytes of the sublittoral zone survive the first winter equally as well as do the spring sporophytes (Table II, no. 7; Text-fig. 2). At I year old $86 \%$ of a summer population has gone from the substratum, and at 2 years old $99 \cdot 2 \%$ of the original population, a figure only slightly higher than for a spring population. The small percentage, $0.8 \%$, that lives through the third summer disappears during the third winter at an age of about $2 \frac{1}{2}$ years. As in spring sporophytes developed in the sublittoral zone, the heaviest losses in numbers of summer sporophytes, after the first year of growth, occur during two periods of the year, late spring-summer and winter (Text-fig. 2).

There is no indication from the normal populations of $L$. saccharina examined that any plants reach the fourth year of growth, even plants unattached in the sublittoral zone. From the foregoing data it is suggested that the life-span of the sporophyte of $L$. saccharina, on the coasts of Britain, does not exceed 3 years. A study of holdfast, stipe and frond development in first-, second- and third-year plants, the results of which are dealt with in detail in the next section, shows that in this species the peak of growth occurs in the second year of life, thus indicating the short-lived nature of the species.

The information that has been obtained during this work makes it possible to give an indication as to the composition of $L$. saccharina populations in year classes at different levels and in different habitats on the shore during each season of the year. This estimation is given in Table III. The knowledge of the components of a 'normal' population of $L$. saccharina growing in any particular habitat is of importance since from it the approximate extent of the reproductive period of that population can be estimated. 


\section{Table III. The Composition of Laminaria saccharina Populations in Year Classes at Different Levels}

AND IN DifFERENT HabitatS DURING EACH SEASON OF THE YEAR

\begin{tabular}{|c|c|c|c|c|c|c|c|c|c|c|c|c|c|c|c|c|}
\hline Season of the year $\quad \ldots \quad \ldots \quad \quad \ldots$ & & Wir & nter & & & Spr & ring & & & Sum & nmer & & & Aut & tumn & \\
\hline $\begin{array}{l}\text { Time of year populations were produced ... } \\
\text { Nature of habitat: }\end{array}$ & Winter & Spring & Summer & Autumn & Winter & Spring & Summer & Autumn & Winter & Spring & Summer & Autumn & Winter & Spring & Summer & Autumn \\
\hline Exposed coast, intertidal and sublittoral & Ist †* & Ist & Ist & Ist & - & Ist $\dagger$ & Ist & Ist & - & Ist & rst + & $\mathrm{Ist}^{\star}$ & - & Ist & Ist & Ist + \\
\hline fringe zones; emergence at spring tides & - & and & - & - & - & 2nd & - & - & - & 2nd & $2 \mathrm{nd}^{\star}$ & - & - & 2nd & - & - \\
\hline & - & - & - & - & - & $3 \mathrm{rd}^{\star}$ & - & - & - & - & - & 一 & - & - & - & - \\
\hline $\begin{array}{l}\text { Exposed coast, intertidal and sublittoral } \\
\text { fringe zones, in pools }\end{array}$ & Ist - & $\begin{array}{l}\text { Ist } \\
\text { 2nd }\end{array}$ & $\begin{array}{l}\text { Ist } \\
2 \text { nd }^{\star}\end{array}$ & Ist & 二 & $\begin{array}{l}\text { Ist } \\
\text { 2nd }\end{array}$ & Ist & Ist & 二 & $\begin{array}{l}\text { Ist } \\
\text { 2nd }\end{array}$ & $\begin{array}{l}\text { rst } \\
\text { 2nd }\end{array}$ & rst* & 二 & $\begin{array}{l}\text { Ist } \\
\text { 2nd }\end{array}$ & $\begin{array}{l}\text { rst } \\
\text { 2nd }\end{array}$ & Ist† \\
\hline & - & $3 \mathrm{rd}^{\star}$ & - & - & 一 & 3 rd & - & - & - & 3 rd & - & - & - & 3 rd & - & - \\
\hline Exposed coast, sublittoral zone, & - & Ist & rst & Ist & - & Ist & Ist & Ist & - & Ist & Ist $\dagger$ & ist & - & Ist & Ist & ist \\
\hline I-4 m. below E.L.W.S.T. & - & 2nd & $2 \mathrm{nd}^{\star}$ & $2 \mathrm{nd}^{\star}$ & - & 2nd & - & - & - & 2nd & 2nd & - & - & 2nd & 2nd & 2nd \\
\hline & 一 & $3 \mathrm{rd}^{\star}$ & - & - & - & 3 rd & - & - & - & 3 rd & - & - & - & 3 rd & - & - \\
\hline Sheltered coast, intertidal and sublittoral & ist $\dagger$ & rst & Ist & Ist & Ist & Ist & Ist & Ist & Ist & rst & rst $\dagger$ & rst & rst & Ist & Ist . & Ist $\dagger$ \\
\hline fringe zones; emergence at spring tides, & 2nd & 2nd & 2nd & 2nd & . 2nd & 2nd & 2nd & 2nd & 2nd & 2nd & 2nd & 2nd & 2nd & 2nd & 2nd & 2nd \\
\hline or in pools & 3 rd & $3 \mathrm{rd}^{\star}$ & $3 \mathrm{rd}^{\star}$ & $3 \mathrm{rd}^{\star}$ & 3 rd & 3 rd & - & - & 3 rd & 3 rd & 3 rd & - & 3 rd & 3 rd & 3 rd & 3 rd \\
\hline 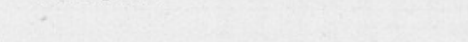 & 4 th* & - & - & - & - & - & 一 & - & - & - & - & - & - & - & - & - \\
\hline Sheltered coast, sublittoral zone, & - & Ist & Ist & I st & - & rst† & Ist & Ist & - & Ist & rst† & rst & - & Ist & Ist & Ist $\dagger$ \\
\hline I-4 m. below E.L.W.S.T. & - & 2nd & 2nd & 2nd & - & 2nd & 2nd & 2nd & - & 2nd & 2nd & 2nd & - & 2nd & 2nd & 2nd \\
\hline & - & $3 \mathrm{rd}^{\star}$ & $3 \mathrm{rd}^{\star}$ & $3 \mathrm{rd}^{*}$ & - & 3 rd & - & - & - & 3 rd & 3 rd & - & - & 3 rd & 3 rd & $3 \mathrm{rd}$ \\
\hline
\end{tabular}




\section{GROWTH OF THE SPOROPHYTE}

Although the sporophyte of $L$. saccharina shows continuous growth throughout its life, very considerable variation occurs in the rate of the growth in both the frond and the stipe during the different seasons of the year. The change in the rate of growth with the time of the year produces periods of rapid and slow growth which alternate during the life of the sporophyte. As the rate of growth of the sporophyte rises gradually to a maximum and then drops gradually to a minimum during each yearly cycle two growth periods, one 'rapid' and one 'slow', are distinguished in each yearly cycle in the development of this species. The 'period of rapid growth' starts in January and continues until June-July with the most rapid growth taking place from March to June, whilst the 'period of slow growth' is from July to December with the slowest growth occurring between September and December.

The sporelings show variation also in the rate of development with the time of the year at which they arise, developing very much more rapidly during the rapid-growth period of the older plants than during the slow-growth period. For instance, sporophytes developing on experimental areas at Wembury reached $20 \mathrm{~cm}$. in length in 4 weeks when they arose during the months of April and May, but when development started in November the sporelings grew very slowly, reaching a length of only $2 \mathrm{~cm}$. in 4 weeks. Similar results were obtained in cultures set up in the laboratory at Plymouth. Here zygotes of $L$. saccharina, developing during the months of November and December, took 6 weeks to produce sporophytes with a length of from 2 to $3 \mathrm{~cm}$. At this stage complete differentiation into stipe and frond had been attained and the first row of true haptera had been formed and was attached.

\section{Plate V. Laminaria saccharina (L.) Lamour.}

Photographs of different-aged plants from a population that arose in April 1943 on a cleared experimental area on the Blackstone Rocks, Wembury, Devon. Fairly exposed habitat in the intertidal zone (0.2 m. above M.L.W.S.T.) with shallow submergence at low water of mean spring tides. $\times \frac{1}{20}$.

Fig. I. Three-months-old plant-sterile. 21. vi. I943.

Fig. 2. Seven-months-old plant-immature reproductive tissue. I5. xi. 1943.

Fig. 3. Eight-months-old plant-mature reproductive tissue: first sporulation. 9. xii. 1943.

Fig. 4. Ten-months-old plant-mature reproductive tissue. 28. i. I944.

Fig. 5. Twelve-months-old plant-liberation of zoospores practically ceased. 28. iii. I944.

Fig. 6. Thirteen-months-old plant-sterile. 25. iv. I944.

Fig. 7. Fourteen-months-old plant-sterile. 24. v. I944.

Fig. 8. Sixteen-months-old plant-immature reproductive tissue, 8. viii. 1944.

Fig. 9. Sixteen-months-old plant-mature reproductive tissue. 8. viii. 1944.

Fig. Io. Eighteen-months-old plant-mature reproductive tissue. I. x. I944.

Fig. II. Nineteen-months-old plant-mature reproductive tissue. 2. xi. 1944.

Fig. I2. Twenty-months-old plant-mature reproductive tissue. I. xii. I944.

Fig. I3. Twenty-one-months-old plant-mature reproductive tissue. 30. xii. I944.

Fig. I4. Twenty-two-months-old plant-mature reproductive tissue. I5. i. 1945. 


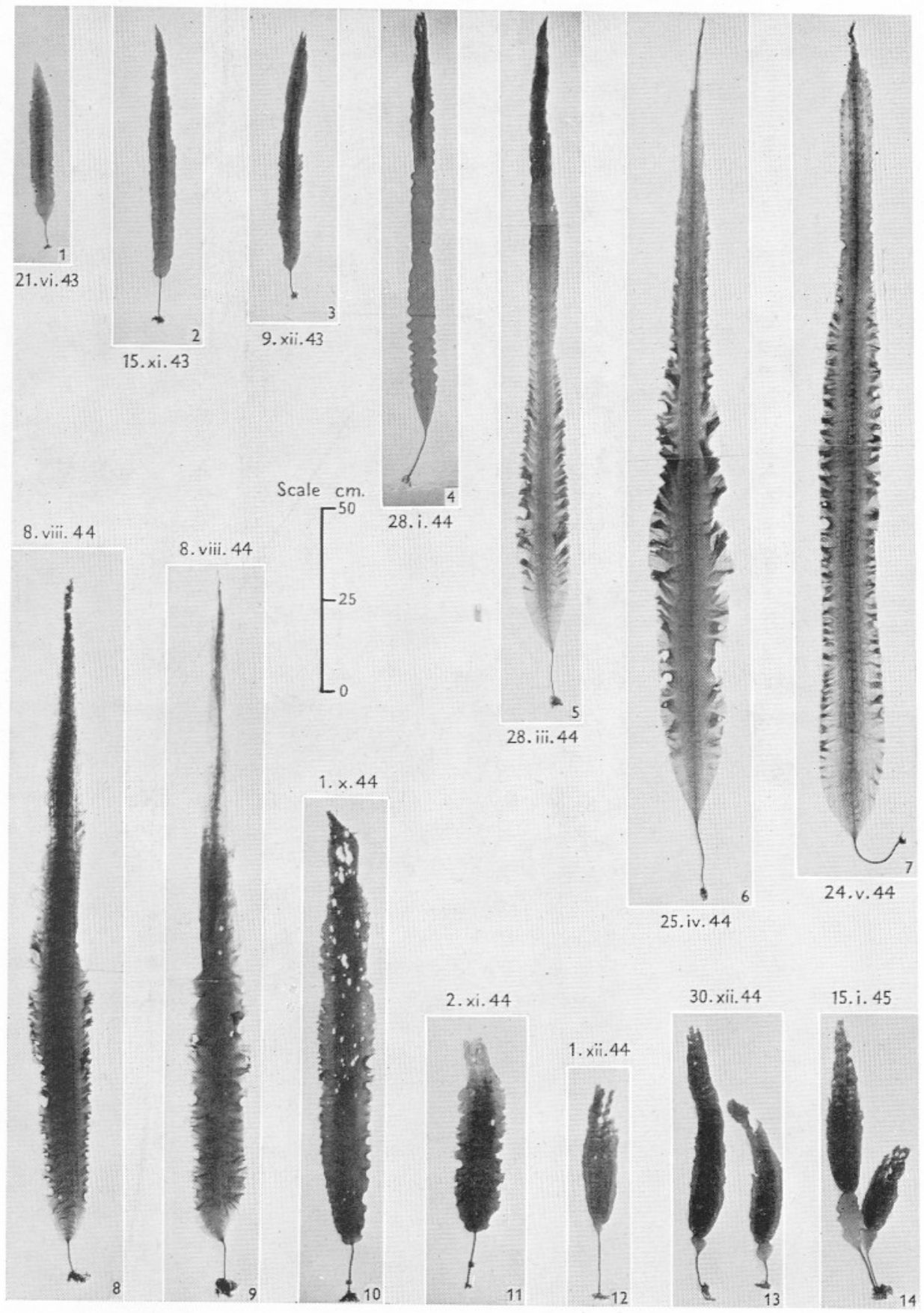

Figs. I-I4. 
In the frond the change in the rate of the growth throughout a yearly cycle is indicated by the change in the shape of the base and also by the variation in the width of the tissue produced during the different seasons (Pls. V-VII, IX-XI). As tissue is cast off from the distal end of the frond normally when it reaches the age of 6 or 7 months (Pls. IX-XI), a population must be examined at intervals throughout a complete year if the change in frond width is to be followed.

The periods of varying rate of growth can be seen reflected most clearly, however, in the perennial part of the sporophyte, in the alternate light and dark 'ring' formation (Pl. XIII) that shows in the stipe and holdfast, the darker 'rings' being formed by the tissue developed during the periods of slower growth.

\section{GROWTH OF THE FROND}

The growth in length of the frond, the variation in the frond width and the loss of distal (apical) frond tissue have been followed in L. saccharina plants (sporophytes), developing under different habitat conditions on the shore, from the earliest visible stages up to the age of approximately 2 years.

Pls. IX-XI have been compiled from the records of plants of known age growing on experimental areas. Pl. IX covers the period from March I942, when the plants were first visible on the shore, to April I944, the month in which the last record was taken before the plants disappeared. This diagram illustrates the behaviour of frond tissue on plants, growing intertidally on an exposed shore, in habitats which are uncovered when low water is at the level of mean springs.

For the sake of contrast to the above, plants were studied growing at the same level on the same shore, but remaining permanently submerged in pools. Pl. X illustrates the growth of such plants, covering a period of 2 years and 3 months from April 1943, when the plants germinated.

In Pl. XI growth of the frond of summer-developed plants in the upper part of the sublittoral zone ( $\mathrm{I} \mathrm{m}$. below E.L.W.S.T.) is illustrated, and coyers also a period of 2 years from July 1942 to July 1944 .

In the diagrams on Pls. IX-XI the thick line running through and across the columns joins up the average actual frond length of the population at the times of measurement, the length of the column above this line indicating the average amount of frond length that has been cast off by the population up to that date since the time of germination. The thin line joining up the tops of the columns gives the curve for the overall growth in length of the frond, including the cast-off tissue.

The solid block at the base of each of the columns shows the average length of frond added by the population since the previous measurement, whilst the hatched part of the column, immediately above the thick line denoting frond 
length, gives the average amount of frond tissue that has been cast off by the population since the previous measurement.

In the final column of each of the three diagrams are shown: (i) the total average frond length that has been produced by a plant of each of the populations during the complete period of observation, and (ii) the variation in the average width of the frond, at the same scale as frond length, throughout the whole period. On the left side of these final columns the average monthly growth in the length of the frond is marked off, and on the right side of the columns is recorded the approximate period during which each month's frond tissue is cast.

\section{Growth in Length}

\section{General Rhythm in Rate of Growth}

The general rhythm in the rise and fall in the rate of growth in length of the frond during a yearly cycle in any L. saccharina population can be seen from an examination of Pls. IX-XI and Text-fig. 3. These figures show that in general, whatever the age, habitat, latitude or time of germination of the population, frond growth in length is at a more rapid rate from January to June-July than from July-August to December. They show also that during the period of more rapid growth, January to June, the rate of growth gradually increases from January until March, the rate then either still increasing or remaining fairly stable during the period of the most rapid growth from March to May-June.

Towards the end of the period of rapid growth the rate begins to slow down, gradually decreasing from June-July onwards during the period of slower growth, July to December, until the minimum rate is reached during the months of either October or November, after which the rate again begins to rise.

\section{Plates VI and VII. Laminaria saccharina (L.) Lamour.}

With the exception of Figs. I5 and 20 the photographs are of different-aged plants from a population that arose in July 1942 on experimental blocks situated off the west coast of the island of Luing, Argyll. Blocks at I m. depth below E.L.W.S.T. in a sheltered habitat. The plant illustrated in Fig. 20 is a second-year plant growing in the same habitat but from a different experimental series. 'Four-holed punch' indicates that four holes were punched in the frond of a plant at $2.5,5.0,7.5$ and $10 \cdot 0 \mathrm{~cm}$. above the base. $\times \frac{1}{20}$.

\section{Plate VI}

Fig. I5. Plants less than 2 months old growing on the stipe of an older plant.

Fig. I6. Plants 3-4 months old-sterile.

Fig. I7. Plants up to 6 months old growing on one of the concrete blocks-sterile.

Fig. I8. Ten-months-old plant-sterile. 22. iv. I943. A, single-hole punch $2.5 \mathrm{~cm}$. above the base, I2. xi. I942; B-C, four-holed punch, 6. ii. I943.

Fig. I9. Twelve-months-old plant-first development of reproductive tissue (immature). 2I. vi. I943. A-B, four-holed punch, 22. iv. I943. This plant was one of the largest

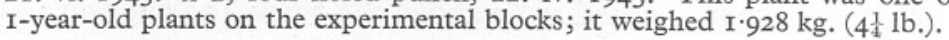



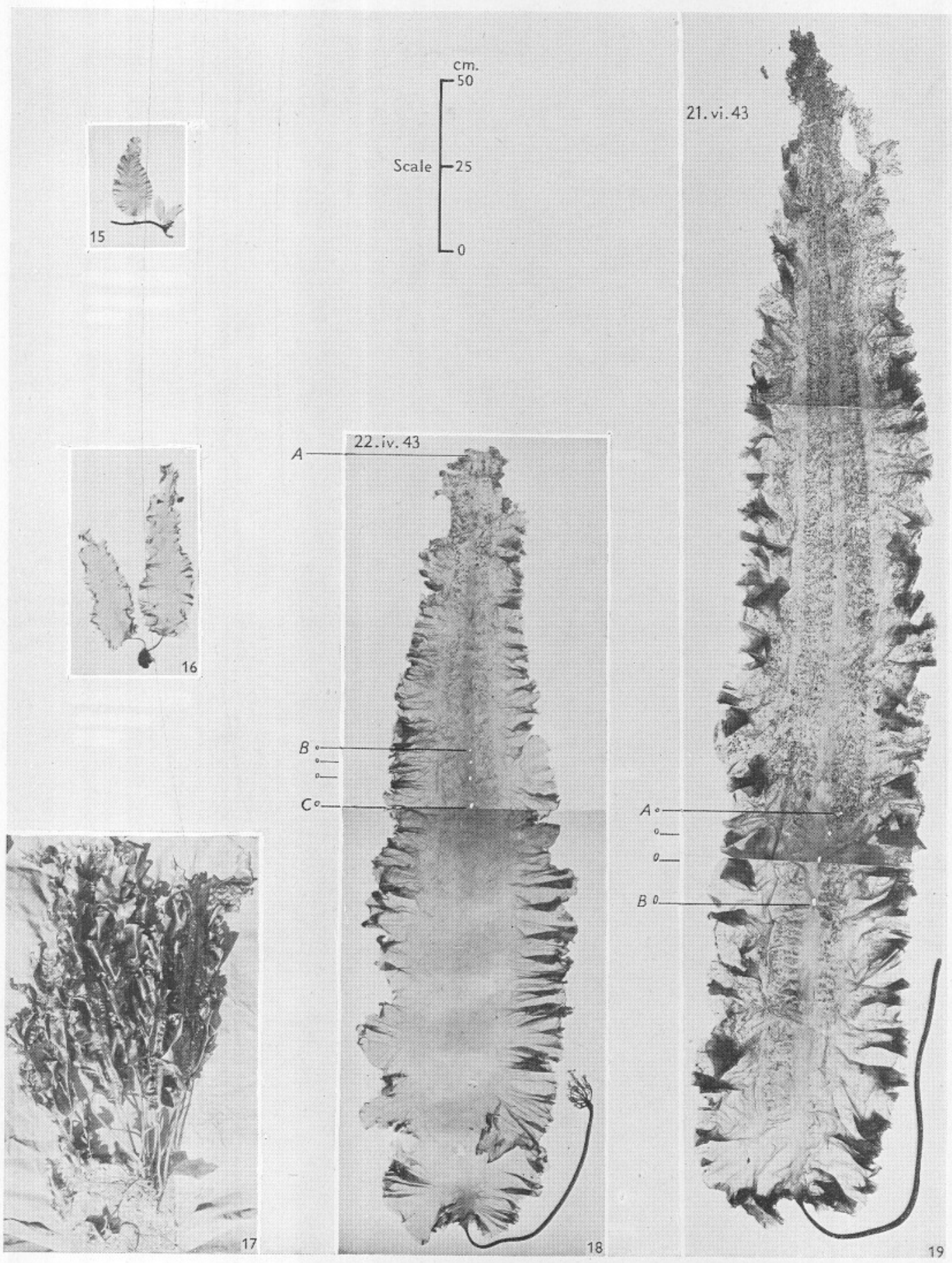

Figs. 15-19. 

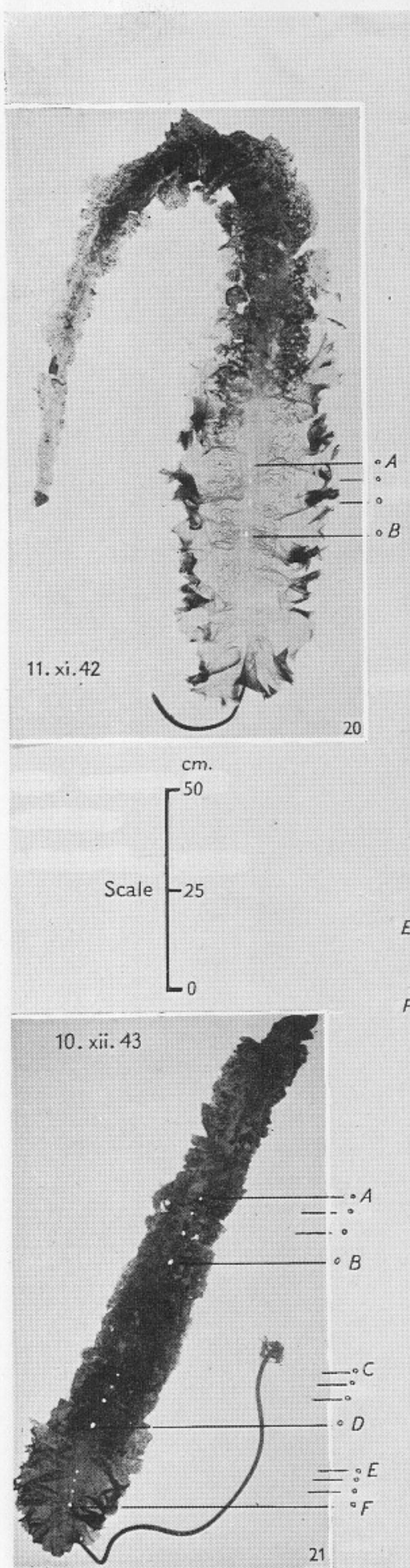
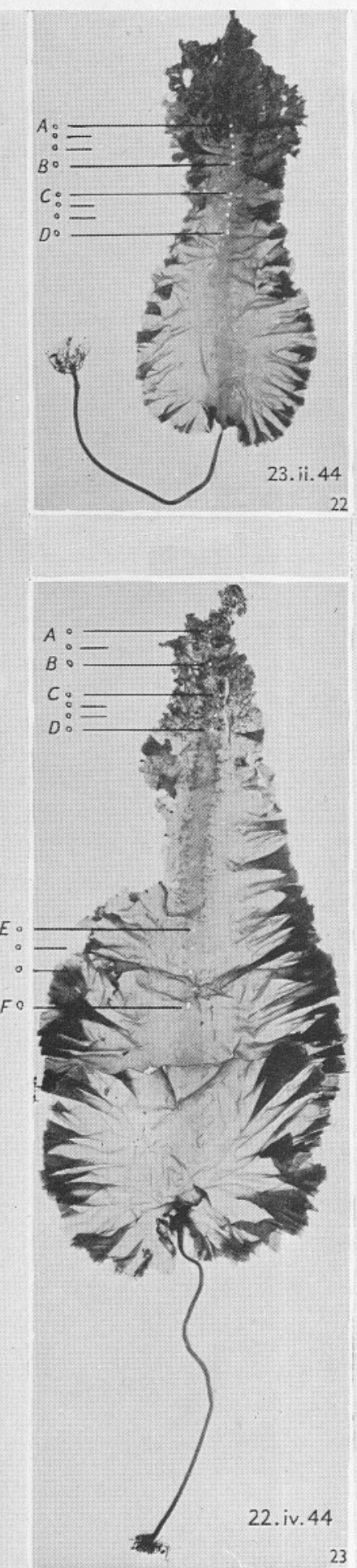

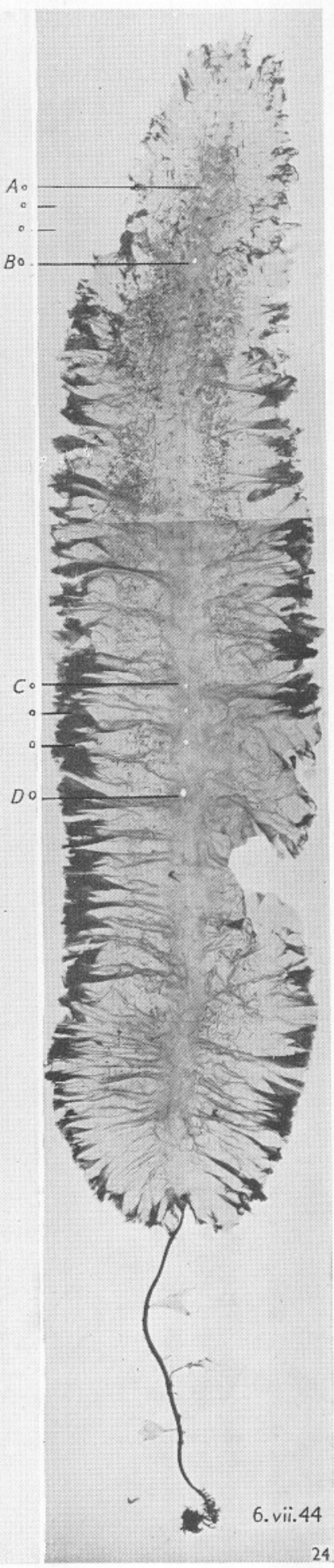

Figs, 20-24. 


\section{Variation in Rate of Growth}

For the variation in the rate of frond growth in length that occurs among the plants of this species, irrespective of the general rhythm in growth-rate that takes place during a yearly cycle, the following factors appear to be responsible: (i) age and season of development of the plant, (ii) habitat, and (iii) geographical position.

In Text-fig. 3, graphs I-6 illustrate the average daily growth in frond length for six populations of $L$. saccharina growing in different types of habitat on the Devon and Argyll coast, and cover periods of from 7 to 27 months. Graphs I, 4 and 6 of this figure give the daily growth in frond length of the three populations illustrated in detail in Pls. IX-XI. The figures given in these graphs can be approximate only, since the average daily growth figure for the period between measurements makes no allowance for any alteration in the rate of growth within any one period. These figures are reproduced as they demonstrate to some extent, first, the change in the rate of frond growth in length throughout the year and the rapidity with which it is possible for frond tissue to be produced (nos. 5, 6); secondly, the change in the rate of growth with the increase in the age of the population (nos. I, 4, 5 and 6) and the difference in rate of growth of populations arising at different times of the year (nos. 5, 6); thirdly, the variation in rate of growth with the type of habitat (nos. I, 4 and 5); and fourthly, the variation in the growth-rate with change in geographical position (nos. 2, 3).

The influence of the age of the plant on the rate of growth in length of the frond can be traced in Pls. IX-XI; Text-fig. 3, nos. I, 4, 5 and 6. The sequence of this variation in rate of growth with increase in age can be seen more clearly when the rate of growth is traced through the successive growth periods in the life of the plant-first, second and third rapid-and slow-growth periods, rather than when followed through yearly cycles starting with the month of germination of the plant.

When growth is traced in the former way the figures show that the rate of frond development in length during the first rapid-growth period is not so

\section{Plate VII}

Fig. 20. Sixteen-months-old plant-mature reproductive tissue. II. xi. I942. A-B, fourholed punch, 16. ix. 1942.

Fig. 21. Eighteen-months-old plant-mature reproductive tissue. Io. xii. I943. A-B, fourholed punch, I6. vi. I943; C-D, four-holed punch, I6. viii. I943; E-F, four-holed punch, I3. x. I943.

Fig. 22. Twenty-months-old plant-mature reproductive tissue. 23. ii. I944. A-B, four-holed punch, I3. x. I943; C-D, four-holed punch, I0. xii. 1943.

Fig. 23. Twenty-two-months-old plant-sterile. 22. iv. 1944. A-B, four-holed punch, I3. X. I 943 (three holes remain); C-D, four-holed punch, IO. xii. I943; E-F, four-holed punch, 23. ii. I944.

Fig. 24. Twenty-four-months-old plant-immature reproductive tissue. 6. vii. 1944. A-B, four-holed punch, 23. ii. I944.; C-D, four-holed punch, 22. iv. I944. 
great as during the second rapid-growth period, and that the rate reached during the third period never surpasses that achieved during the second period.

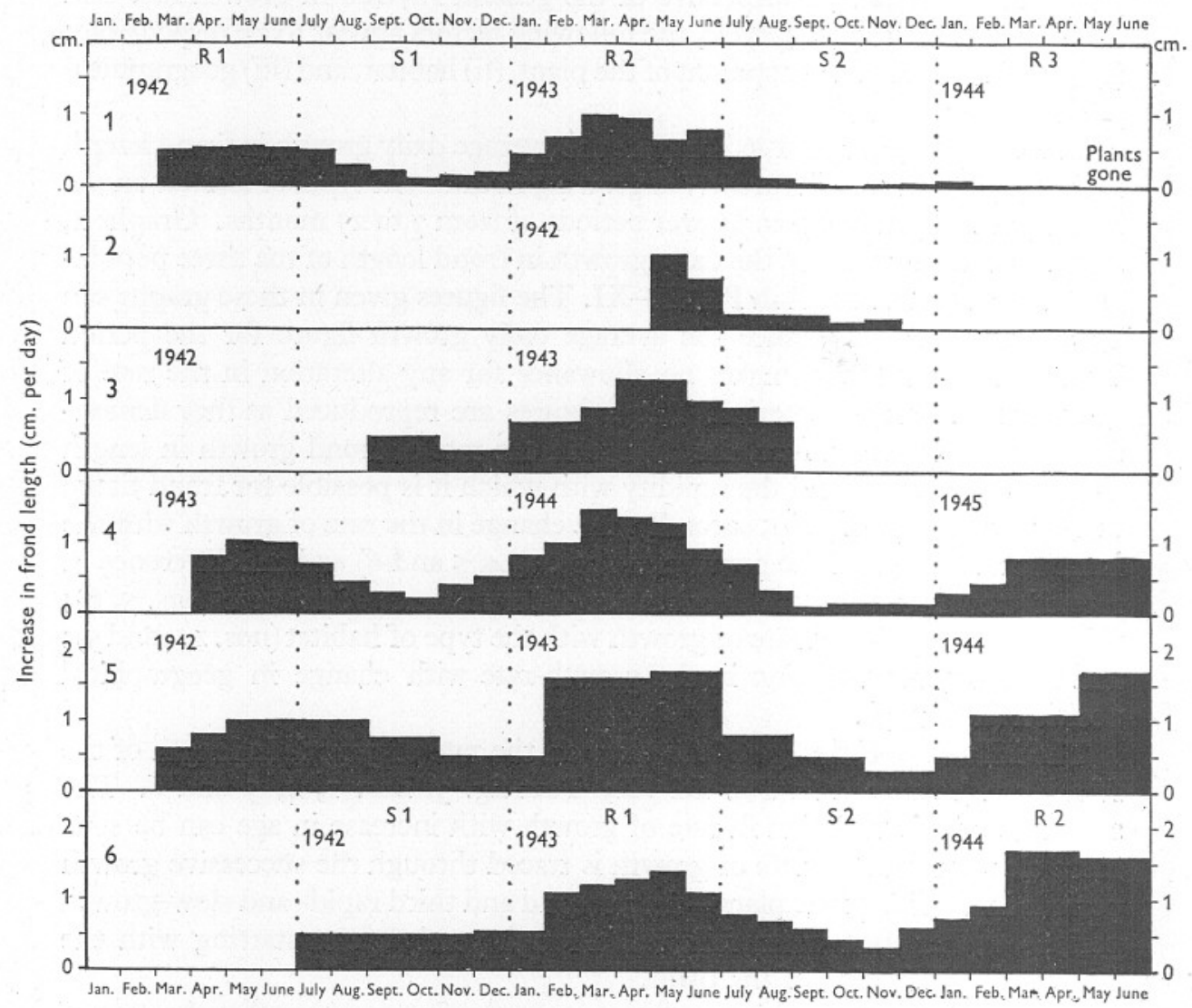

Text-fig. 3. Daily growth in frond length in six populations of $L$. saccharina, showing the variation in growth-rate with age, season, habitat and locality.

(I) Spring population, March I942. Devon, exposed shore, intertidal zone, above M.L.W.S.T. (thus periodically uncovered).

(2) Normal population. Devon, very sheltered shore, intertidal zone, above M.L.W.S.T.

(3) Normal population. Argyll, very sheltered shore, intertidal zone, above M.L.W.S.T.

(4) Spring population, April 1943. Devon, exposed shore, intertidal zone (above M.L.W.S.T.), in pools (thus never uncovered).

(5) Spring population, March 1942. Argyll, sheltered shore, sublittoral zone, at depth of I m. below E.L.W.S.T.

(6) Summer population, July I942. Argyll, sheltered shore, sublittoral zone, at depth of I m. below E.L.W.S.T.

$\mathrm{R}$, rapid-growth period. S, slow-growth period.

The variability in the rate of frond growth during the third rapid-growth period, when compared with the growth during the second rapid-growth 
period in the same habitat, is so pronounced among populations growing in different habitats that factors external to the plant appear responsible and will be discussed later (compare Pls. IX, X; Text-fig. 3, nos. I, 4 and 5).

During the slow-growth periods, however, the rate does not slow down to the same degree, nor does the slowest rate persist for so long a time during the

Jan. Feb. Mar. Apr. May June July Aug. Sept. Oct. Nov. Dec. Jan. Feb. Mar. Apr. May. June July Aug. Sept. Oct. Nov. Dec. Jan. Feb. Mar. Apr. May June

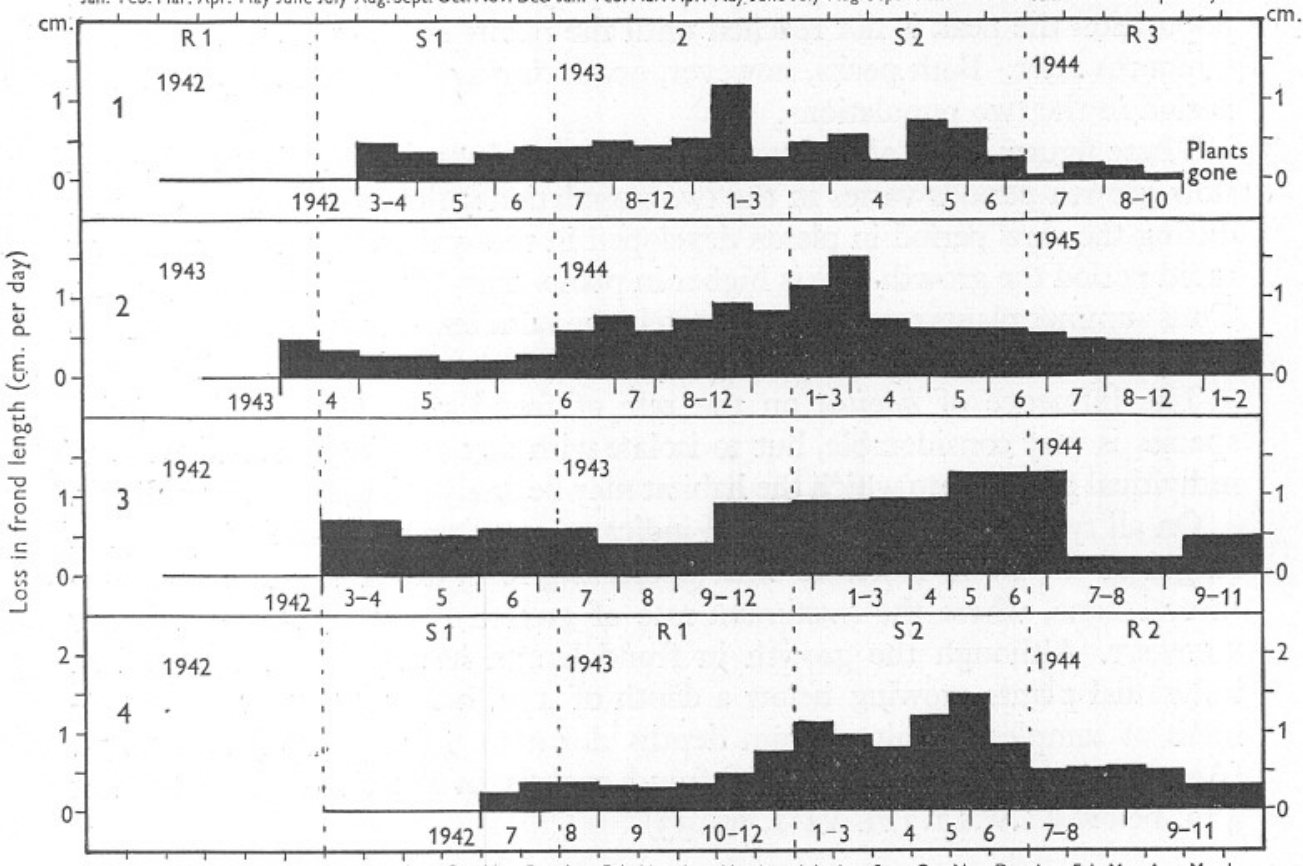

Jan. Feb. Mar. Apr. May June July Aug. Sept. Oct. Nov, Dec, Jan. Feb. Mar. Apr. May June July Aug. Sẹpt. Oct. Nov. Dec. Jan. Feb. Mar. Apr. May June

Text-fig. 4. Daily loss in length of frond in four populations of L. saccharina, showing the variation with age, season and habitat.

(I) Spring population, March 1942. Devon, exposed shore, intertidal zone (above M.L.W.S.T.).

(2) Spring population, April 1943. Devon, exposed shore, intertidal zone (above M.L.W.S.T.), in pools.

(3) Spring population, March 1942. Argyll, sheltered shore, sublittoral zone, at depth of I m. below E.L.W.S.T.

(4) Summer population, July 1942. Argyll, sheltered shore, sublittoral zone, at depth of I m. below E.L.W.S.T.

The numbers below each diagram give the month during which the frond tissue concerned was developed. $\mathrm{R}$, rapid-growth period. $\mathrm{s}$, slow-growth period.

first slow-growth period as during the second, whilst during the third period the growth-rate is so slow that it is practically negligible.

Although the peak in growth-rate may vary with habitat and geographical position, the maximum rate of frond growth in length is reached in all populations during the second rapid-growth period in the life of a plant of this species; 
the actual age in months at which the peak occurs being dependent on the time of germination of the plant.

For example, graphs 5 and 6 of Text-fig. 3 show the daily growth-rate of two groups of $L$. saccharina plants growing in the same habitat; in no. 5 development of the plants started in the spring (March), whilst in no. 6 development did not start until the summer (July). In the spring population the peak of growth is reached when the plants are about 15 months old, but in the summer population the peak is not reached until the plants are about $2 \mathrm{I}$ months old, 6 months later. Both peaks, however, occur during the second rapid-growth period in the two populations.

These figures show also that the rate of growth during the first rapid- and slow-growth periods varies in the two populations; the growth-rate is higher during the slow period in plants developed in the spring, but during the first rapid period the growth-rate is higher in plants that developed in the summer. Thus summer plants reach approximately the same length as I2- to I3-monthsold spring-developed plants when they are from 9 to Io months old.

The influence of habitat on the rate of frond growth in length of this species is very considerable, but to isolate with any certainty the influence of individual factors into which the habitat may be analysed is extremely difficult.

On all types of shore the general indications are that the rate of growth in length of the frond increases with decreasing level down to the upper sublittoral zone, where the maximum rate of growth is reached I-4 m. below E.L.W.S.T. Although the growth in frond length has not been followed in individual plants growing below a depth of $4 \mathrm{~m}$. below E.L.W.S.T., measurement of samples examined from depths down to $8 \mathrm{~m}$. (Devon) and $12 \mathrm{~m}$. (Argyll) showed that the rate of frond growth in length was less than at 4 m. below E.L.W.S.T. (Pl. VIII, fig. 33).

\section{Plate VIII. Laminaria saccharina (L.) Lamour.}

Photographs of plants from different types of habitat. Figs. 25, 27 and 28 are of summerdeveloped plants growing on the Argyll coast in the intertidal zone in a fairly exposed habitat with emergence at low water of mean spring tides. Figs. 29-3I are of spring-developed plants growing on the Devon coast in the intertidal zone in a very exposed habitat with emergence at low water of mean spring tides. $\times \frac{1}{20}$.

Fig. 25. Six-months-old plant-sterile. 9. ii. 1943.

Fig. 26. Clump of plants up to 9 months old, from the same habitat as the series on Pl. V, showing different stages in frond regeneration and two plants bearing reproductive tissue. 30. xii. 1943 .

Fig. 27. Ten-months-old plant-sterile. 20. vi. I943.

Fig. 28. Eight-months-old plant-sterile. 22. iv. 1943.

Fig. 29. First-year plant-immature reproductive tissue. 29. xi. I943.

Fig. 30. First-year plant-mature reproductive tissue. 13. xii. I943.

Fig. 3I. Second-year plant-mature reproductive tissue. 28. xii. I943.

Fig. 32. Plant approximately I year old-form of plant growing on raft in Plymouth Sound. 30. iv. I943.

Fig. 33. Plant approximately I year old-form of plant growing on shingle off the Argyll coast at a depth of 12 m. below E.L.W.S.T. 5. vii. I944. 


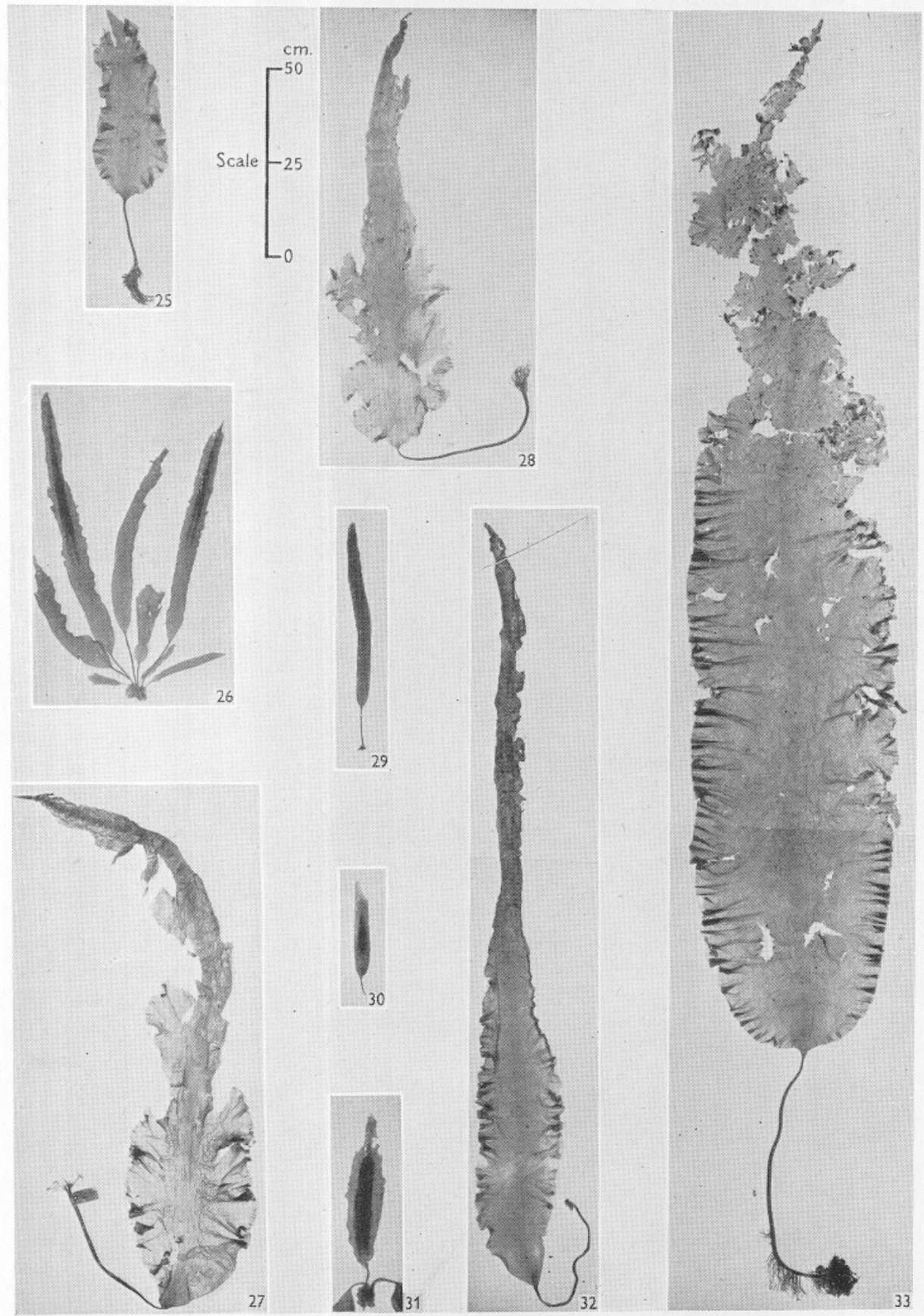

Figs 25-33. 
The records of the maximum growth figures show that at and above E.L.W.S.T. the daily growth in frond length never reaches a figure of $2 \mathrm{~cm}$. increase a day during the rapid-growth period, whilst in the sublittoral zone a daily increase of up to $2 \cdot 3 \mathrm{~cm}$. can be obtained.

In addition to the effect of level on the growth in frond length the influence exerted by two other factors must be taken into consideration. The first of these factors is the degree of exposure or shelter of the habitat; the records show that the rate of growth in frond length increases with the degree of shelter of the habitat. The second factor is that of emergence or submergence of the plants during the period of low tide and concerns only habitats in the intertidal and sublittoral fringe zones. In these zones plants growing on the same shore and at the same level show a higher growth-rate if they remain continuously submerged (pool type), even under a very shallow covering of water, than do the plants which completely emerge during the period of low water (Pls. IX, X; Text-fig. 3, nos. I, 4).

The variability in growth-rate in frond length during the third period of rapid growth, mentioned previously, is almost certainly connected with the depth of immersion of the plants and in consequence also with the factor of level on the shore. If the rates of growth during the second and third rapid-growth periods in the same populations are compared (e.g. in Text-fig. 3, nos. I, 4 and 5), and if this is done for different habitats, the following points can be noted. On exposed coasts populations of plants growing in the intertidal zone above M.L.W.S.T. fail to survive the third period of rapid growth (Text-fig. 3, no. I), showing only slight frond growth from the end of the second period of rapid growth until they disappear during the third period of rapid growth. The amount of frond length added in this type of habitat during the third rapidgrowth period is approximately $4 \%$ only of the length of tissue added during the second period of rapid growth. Populations growing at the same level on the same shore but in pools, even in shallow pools of $30-50 \mathrm{~cm}$. depth during the period of low water, survive the third period of rapid growth and show fair growth (Text-fig. 3, no. 4) during that period; the frond length added, however, during the third period is only $50-60 \%$ of that which is added during the second rapid-growth period. Finally, the populations growing in the upper part of the sublittoral zone ( $\mathrm{I}-4 \mathrm{~m}$. below E.L.W.S.T.) not only survive the third rapid-growth period but show a higher rate of growth during this period than do the two previous types mentioned, producing approximately $85 \%$ of the length developed during the second period (Text-fig. 3, no. 5). The difference in the frond growth-rate in these three populations during the third period of rapid growth is no doubt connected with the variation in the metabolism of the three populations, since Black (I948) has shown that the chemical composition of plants of the same Laminaria species varies at different depths of immersion.

To assess the influence of geographical distribution or of latitude on the growth 
of this species records of growth from many more stations would be required before any clear indication could be obtained. The figures available, however, for the growth of this species on the coasts of Devon $\left(50^{\circ} 18^{\prime} 20^{\prime \prime} \mathrm{N}\right.$., $4^{\circ} 06^{\prime}$ I $5^{\prime \prime}$ W. $)$ and Argyll ( $56^{\circ} \mathrm{I} 4^{\prime} 22^{\prime \prime}$ N., $5^{\circ} 39^{\prime} 40^{\prime \prime}$ W.) suggest, that over this portion of the species' range, the difference in the growth of plants in the two localities might be correlated with the difference in latitude; probably also with differences in the nature of the inshore water at the two stations.

The differences noted are that, with an increase of approximately $6^{\circ}$ in the latitude, there is a higher rate of frond growth throughout the yearly cycle at the more northern station; there also the time when the minimum and maximum rate of frond growth in length is reached is at least I month later than at the more southern station. An examination of the mucilage canals, in the same position on the frond in plants of the same age from the two stations (since Guignard (I892) has indicated these may vary in plants of different ages and in different parts of a single frond), shows that they are larger in the frond tissue of plants at the northern station than at the southern station. So also is the cell size of the frond tissue.

\section{Primary and Secondary Growth in Length}

So far the figures for frond elongation have been given as total increase in length for the whole frond and therefore do not show the differential growthrate or elongation of the frond tissue at successive levels up the frond.

In this species, as in all Laminariales, the main growth region for increase in length is situated in the transition zone between the stipe and the frond, and so any tissue which forms below a level of $2.5 \mathrm{~cm}$. above the base of the frond will be classed as primary growth, that is, new tissue formation, since below the $2.5 \mathrm{~cm}$. level the differentiation of frond tissues is not complete, neither is the mucilage canal system developed. Above the $2.5 \mathrm{~cm}$. level any increase in length of the tissues will be classed as secondary growth, this term including both increase in length by cell division and elongation by enlargement of the cells of the tissues already developed. Table IV and Text-fig. 5 give the primary and secondary elongation of frond tissue that took place in one plant from the age of 4 to 24 months, and illustrates the general method of frond growth in this species. The figures for elongation are obtained from the measurements of the distances between series of holes in the frond, punched at approximately 2 -monthly intervals at $2.5,5.0,7.5$ and $10.0 \mathrm{~cm}$. up from the base (Pls. VI, VII).

Primary growth throughout the yearly cycles follows the general rhythm of periods of rapid and slow growth described earlier, the peak in primary growth being reached during the months of March and April, when a frond in the first and second rapid-growth periods can show a $54 \%$ and a $69 \%$ increase respectively per day in basal elongation. The minimum rate of growth for the 


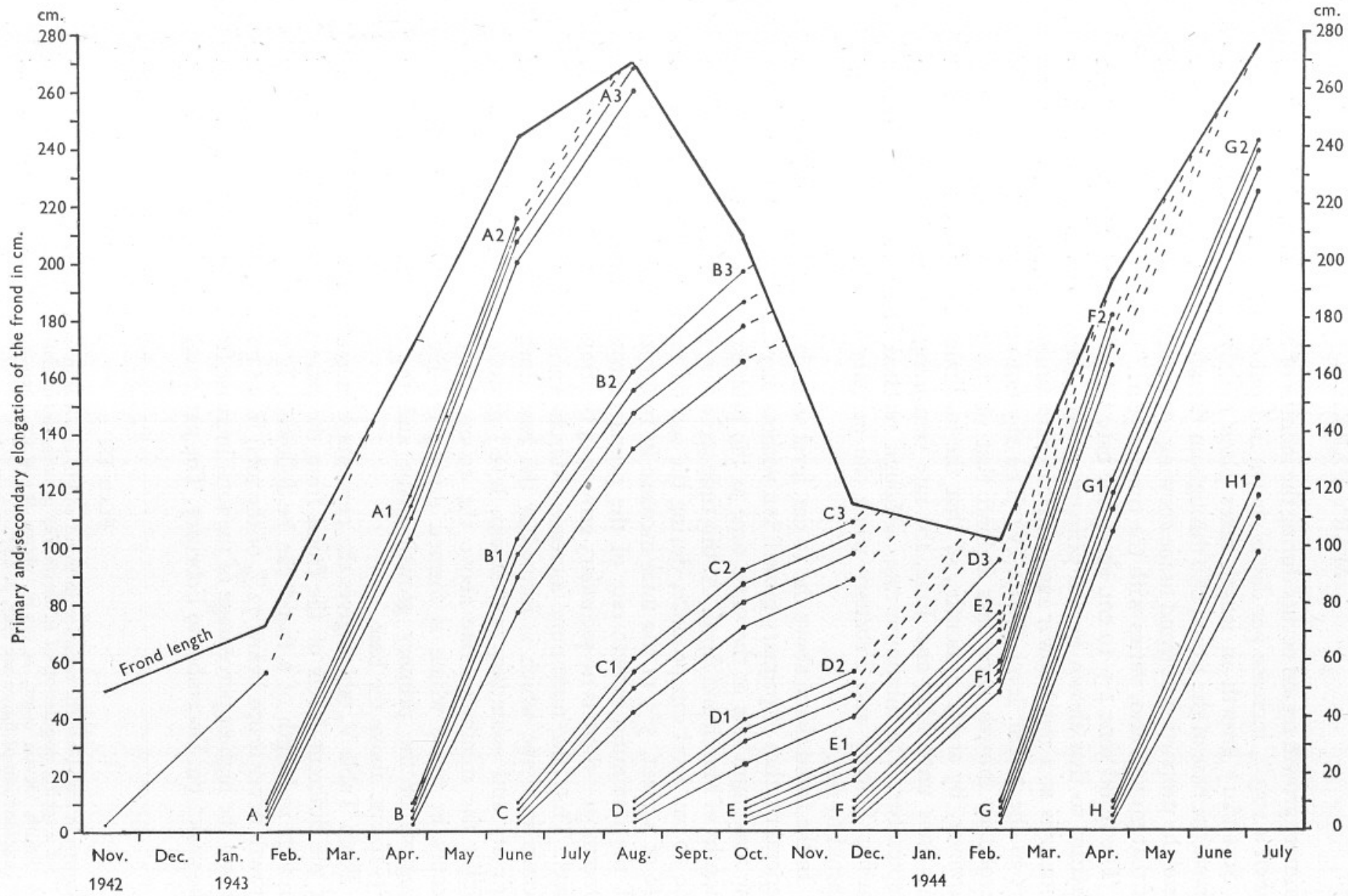

Text-fig. 5. Primary and secondary elongation of the frond in a plant of $L$. saccharina from the 4th to the 24th month of growth, illustrated by means of holes punched in the frond at $2 \cdot 5,5 \cdot 0,7 \cdot 5$ and $10.0 \mathrm{~cm}$. above the base. Plant germinated July 1942 in the sublittoral zone on the Argyll coast at a depth of $\mathrm{I}$ m. below E.L.W.S.T. 
primary growth region occurs during the months of November and December, when a 10.3\% increase per day is shown in basal elongation.

Secondary growth in length takes place mainly in the zone $2.5-10 \mathrm{~cm}$. above the base of the frond, also throughout the whole year. Above the $10 \mathrm{~cm}$. level the proportion of frond tissue showing secondary growth, and the amount of that growth also, varies with the time of year.

The frond zone $2.5-10 \mathrm{~cm}$. above the base follows a similar type of growth rhythm to that shown by the primary growth zone, but the growth in the former is at a much lower rate, with the rate diminishing upwards from the 2.5 to the $10 \mathrm{~cm}$. level (Table IV). The rhythm of the growth-rate in this secondary growth zone lags behind that of the primary-growth rhythm, however, by about 2 months, so that the maximum rate is not reached in this zone until May and June, the rate remaining still high until AugustSeptember. The minimum rate, although reached in December, continues during January and February when the primary growth-rate has already started to rise.

In the frond tissue above the $10 \mathrm{~cm}$. level secondary growth also follows the general rhythm of primary growth but without any time lag, and thus reaches the maximum rate at the same time as the primary growth zone during the months of March and April. At this time secondary growth in the tissue above the $10 \mathrm{~cm}$. level can produce, during the second rapid-growth period in the life of a plant, $5 \%$ of the total increase in frond length. During the period of the minimum growth-rate of the primary growth tissue-November to December-there is no secondary growth in the frond tissue above the $10 \mathrm{~cm}$. level. Thus the maximum increase (March-April) above the $10 \mathrm{~cm}$. level occurs in tissue which is formed at the base during the minimum rate of primary and secondary $(2.5-10 \mathrm{~cm}$. level) growth (October to December), whilst the minimum rate above the $10 \mathrm{~cm}$. level (October to December) occurs in tissue which is formed during the high growth-rates (June to August) of the primary growth tissue and the secondary growth tissue $2 \cdot 5-10 \mathrm{~cm}$. above the base.

From Table V, which gives the percentage increase in length of the tissue at the different levels of the frond from the base upwards, the method of growth in length of a frond can be followed. It can be seen that primary growth never drops below $72 \%$ of the total frond growth in length and that it shows the highest percentage of the total increase from October to April with the peak from December to February. The percentage of primary growth then

\section{Plate IX}

Growth in frond length, variation in frond width, and loss in frond length throughout the life of a spring population of L. saccharina growing intertidally on an exposed shore, on the South Devon coast, at $0.2 \mathrm{~m}$. above M.L.W.S.T. (hence periodically uncovered). For explanation of figure see text, p. 667. 


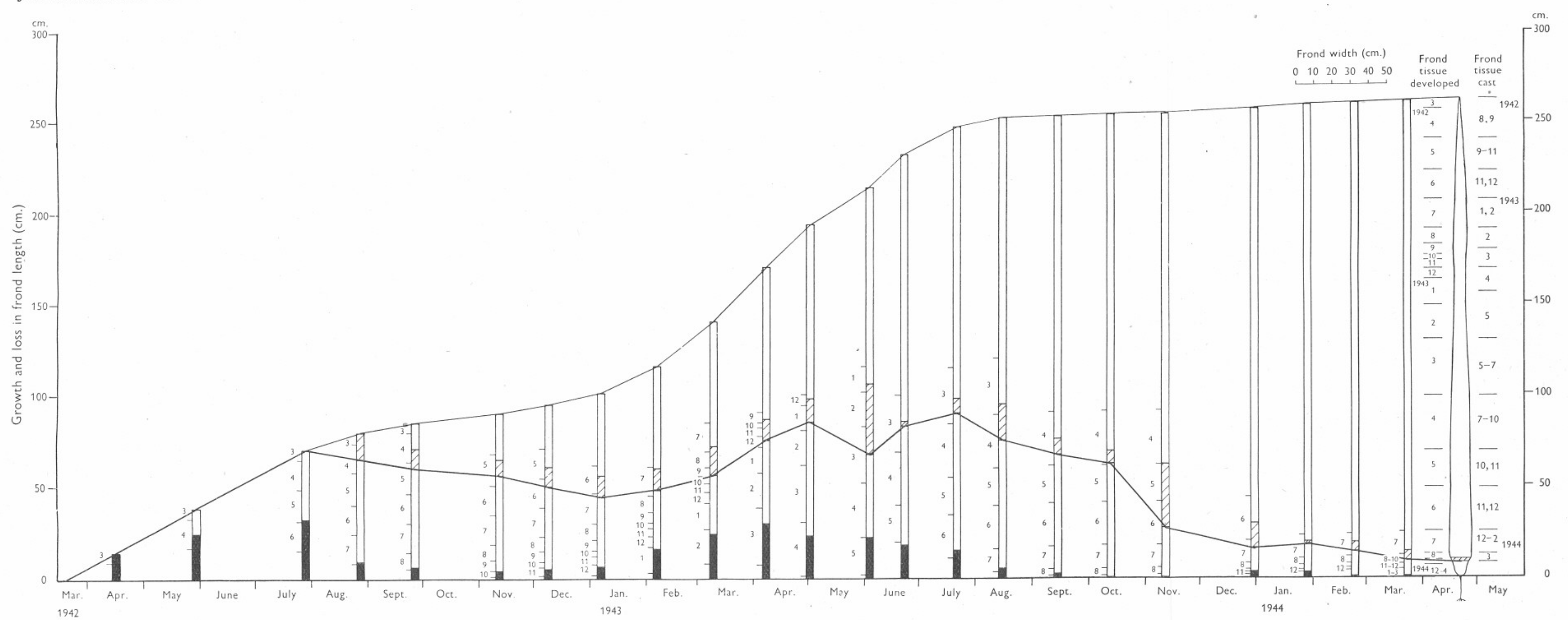


falls from April to October as the percentage of secondary growth in the $2.5-10 \mathrm{~cm}$. zone above the base rises; the highest percentage increase in this tissue being recorded from August to October when the lowest percentage for primary growth is recorded. In the frond tissue above the $10 \mathrm{~cm}$. level the highest percentage increase is from February to April in the tissue 3-4 months old with a decrease from April to June as in the primary tissue. In this tissue,

\section{Table V. Relative Increase in Frond Length at different Frond Levels in a Plant of Laminaria SACCHaRINa from the Seventh TO THE TWENTY-FOURTH MONTH OF GROWTH}

Percentage of total increase

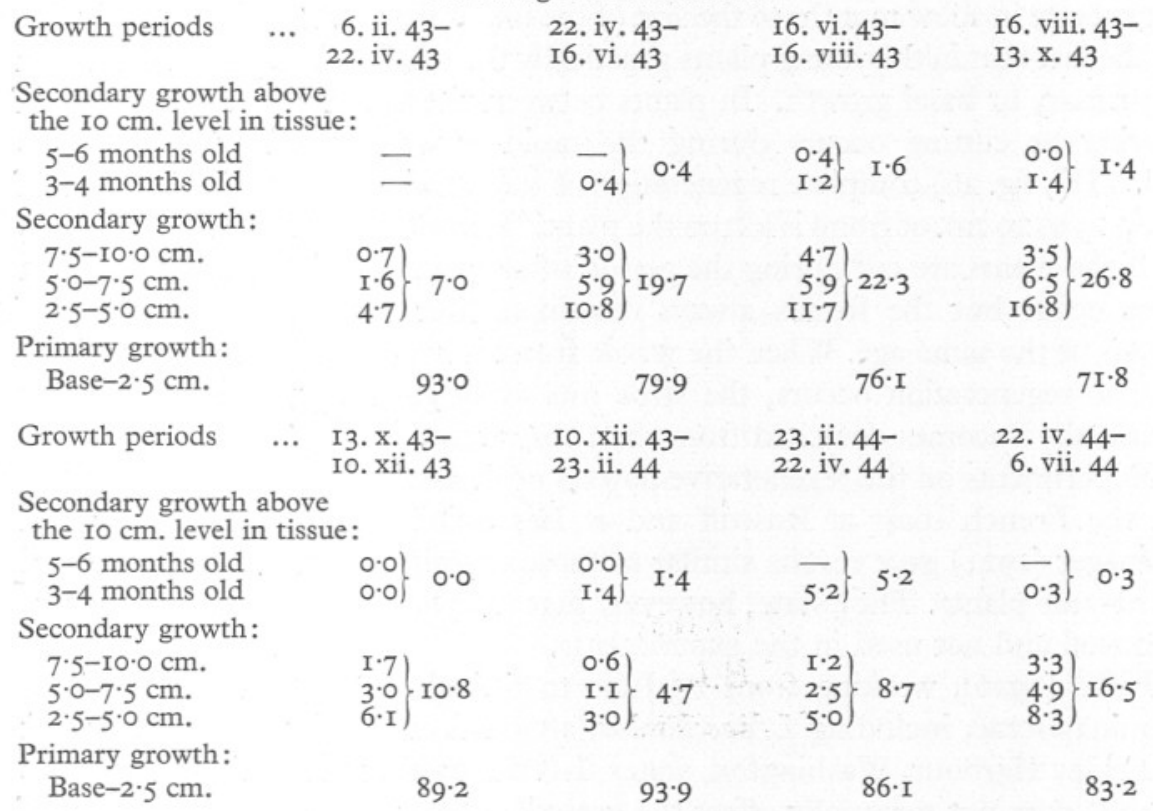

however, the percentage increase then rises again from June to September before growth ceases during the months from October to December.

The frond growth illustrated above is of a plant growing on the Argyll coast; in plants growing on the Devon coast, however, the peaks of primary growth and secondary growth above the $10 \mathrm{~cm}$. level are reached during February and March, and that of secondary growth at the $2.5-10 \mathrm{~cm}$. level during April and May, the growth peaks, therefore, occurring a month earlier than on the Argyll coast.

\section{Regeneration of the Frond}

From the results of the experiments in which $L$. saccharina fronds were cut to a length of 5 , Io and $20 \mathrm{~cm}$., and also by following the growth of labelled 
plants of known age from which the greater part of the frond had been torn off naturally, it has been found that complete regeneration of the frond does not occur in L. saccharina plants over I year old. Plants in the second and third year of growth may persist on the shore for a number of months after the fronds have been torn or cut if approximately $20 \mathrm{~cm}$. of frond remains; they may also show a slight growth in length of the frond during that period, but they do not appear to survive through the winter months following the cutting or tearing of the frond.

During the first year of growth the younger the plant the more complete is the regeneration of the frond after cutting. Fronds of plants up to 3 months old can be cut to $10 \mathrm{~cm}$. from the base at any time of the year and the fronds will regenerate in a few months to the size of the uncut fronds. This is probably due to the fact that in the young plants practically the whole of the growth in length is primary or basal growth. In plants between the age of 3 and 12 months, if tearing or cutting occurs during the rapid-growth period of this species (Pl. VIII, fig. 26) complete regeneration of the frond takes place in 6 months if from 15 to $20 \mathrm{~cm}$. of frond is left on the plant. If less than $15 \mathrm{~cm}$. of frond is left, or if the plants are cut during the period of slower growth, some regeneration does occur but the fronds always remain smaller than the uncut fronds of plants of the same age. When the whole frond is removed from a plant of any age no regeneration occurs, the stipe rots away gradually, and the holdfast eventually becomes detached from the substratum.

Experiments on the regenerative powers of L. saccharina carried out in 1920 on the French coast at Roscoff and at Iles Saint Quay by Freundler and Ménager (I92I) gave results similar to those described above for second- and third-year plants. They state, however, that too young or too old plants were removed and not used in the experiments.

Fallis (I9I6), working from I5 June to 6 August I9I5 on plants of the Laminariaceae, including $L$. saccharina, attached artificially to a floating raft in Friday Harbour, Washington, states that the cutting of the tip of the blade (frond) does not materially effect the growth so long as the basal $5-50 \mathrm{~cm}$. of frond is left, and that larger plants grow faster than the smaller. The age of the 'larger' and 'smaller' plants, however, is not indicated.

\section{Growth in Width}

\section{Variation in Width of Frond throughout Life of Plant}

The width of the tissue developed by the fronds of plants of any age and in any habitat varies throughout a yearly cycle, as does the growth in frond

\section{Plate X}

Growth in frond length, variation in frond width, and loss in frond length throughout the first 27 months of life of a spring population of $L$. saccharina growing intertidally on the same shore as in Pl. IX and at the same level, but remaining permanently submerged in pools. For explanation of figure see text, p. 667 . 
Jan. Feb. Mar. Apr. May June July Aug. Sept. Oct. Nov. Dec. Jan. Feb. Mar. Apr. May June July Aug. Sept. Oct. Nov. Dec. Jan. Feb. Mar. Apr. May June

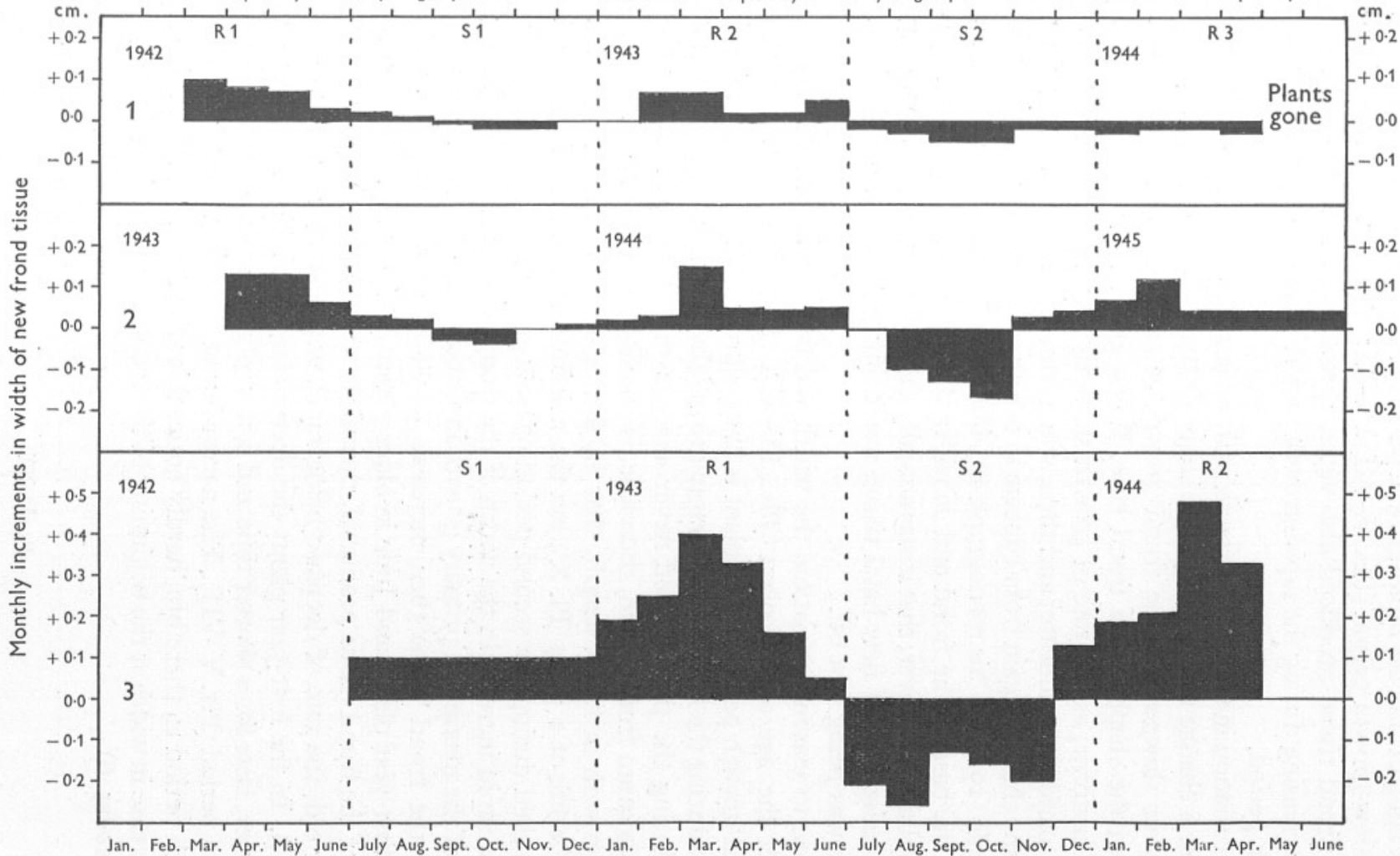

Text-fig. 6. Monthly increments in width of new frond tissue in three populations of $L$. saccharina, showing the variation with age, season and habitat. The figures, expressed in $\mathrm{cm}$. per day, represent the difference (positive or negative) from the width of tissue produced during the previous month.

(I) Spring population, March I942. Devon, exposed shore, intertidal zone, above M.L.W.S.T.

(2) Spring population, April I943. Devon, exposed shore, intertidal zone (above M.L.W.S.T.), in pools.

(3) Summer population, July I942. Argyll, sheltered shore, sublittoral zone, at depth of I m. below E.L.W.S.T. $\mathrm{R}$, rapid-growth period. $\mathrm{S}$, slow-growth period. 
length, increasing during the rapid-growth period of the species and decreasing during the slow-growth period (Pls. V-VII, IX-XI; Text-fig. 6). The thickness of the frond tissue produced also varies throughout a yearly cycle, the thickness decreasing during the rapid-growth period and increasing during the slow-growth period.

With the variation in the rate of growth in frond length and width throughout a yearly cycle a change takes place in the shape of the base of the frond so that the rapidity or slowness of the frond growth at any time can be assessed roughly from the shape of the frond base. When growth is extremely rapid the base is fusiform; as the rate of growth slows down the shape of the base alters from fusiform to cuneate; and then, when frond growth is at a very slow rate, the shape changes again from cuneate to nearly semicircular or subcordate (P1. V). Yendo (I9I9), in his monograph on Alaria, also remarks on the change in shape of the base of the frond and considered it a remarkable process. $\mathrm{He}$ was of the opinion, however, that it was actually the same frond tissue changing shape, not realizing that new basal tissue was being produced whilst the old distal tissue was being cast off.

In addition to seasonal variation, the width and thickness of the frond also change with the age of the plant (Pls. IX-XI). Frond width during the second rapid-growth period of the plant is always greater and the frond tissue thicker than during the first period of rapid growth, but the width and thickness produced during the third period never exceeds that developed during the second. Maximum frond width, therefore, is reached at the same time as the maximum growth in frond length, that is, during the second rapid-growth period in the life of a plant (Pl. X), but the maximum thickness of the frond tissue is reached during the second period of slow growth.

The most rapid increase in the width of the frond tissue takes place during the period of the maximum primary growth in frond length between February and April; the frond tissue then increases in width at a slower rate until August in first-year plants and June in older plants (Text-fig. 6). Decrease in the width of the frond tissue produced, therefore, starts earlier, July, in plants over I year old, the rate of decrease being rapid until October or November (Pls. V-VII). In the first-year plants the decrease in frond width starts about 2 months later, lasts for a shorter time and is not so great as during the second slow-growth period (Pls. V-VII). The narrowing of the frond during the first slow-growth period is, therefore, hardly noticeable when the new frond tissue starts to increase in width at the beginning of the second period of rapid growth (Pl. V; Text-fig. 6).

\section{Plate XI}

Growth in frond length, variation in frond width and loss in frond length throughout the first 24 months of life of a summer population of $L$. saccharina growing in the sublittoral zone on the Argyll coast in a sheltered habitat at a depth of $\mathrm{I}$ m. below E.L.W.S.T. For explanation of figure see text, p. 667. 
JourN. MAR. BIOL. Assoc. XXVII

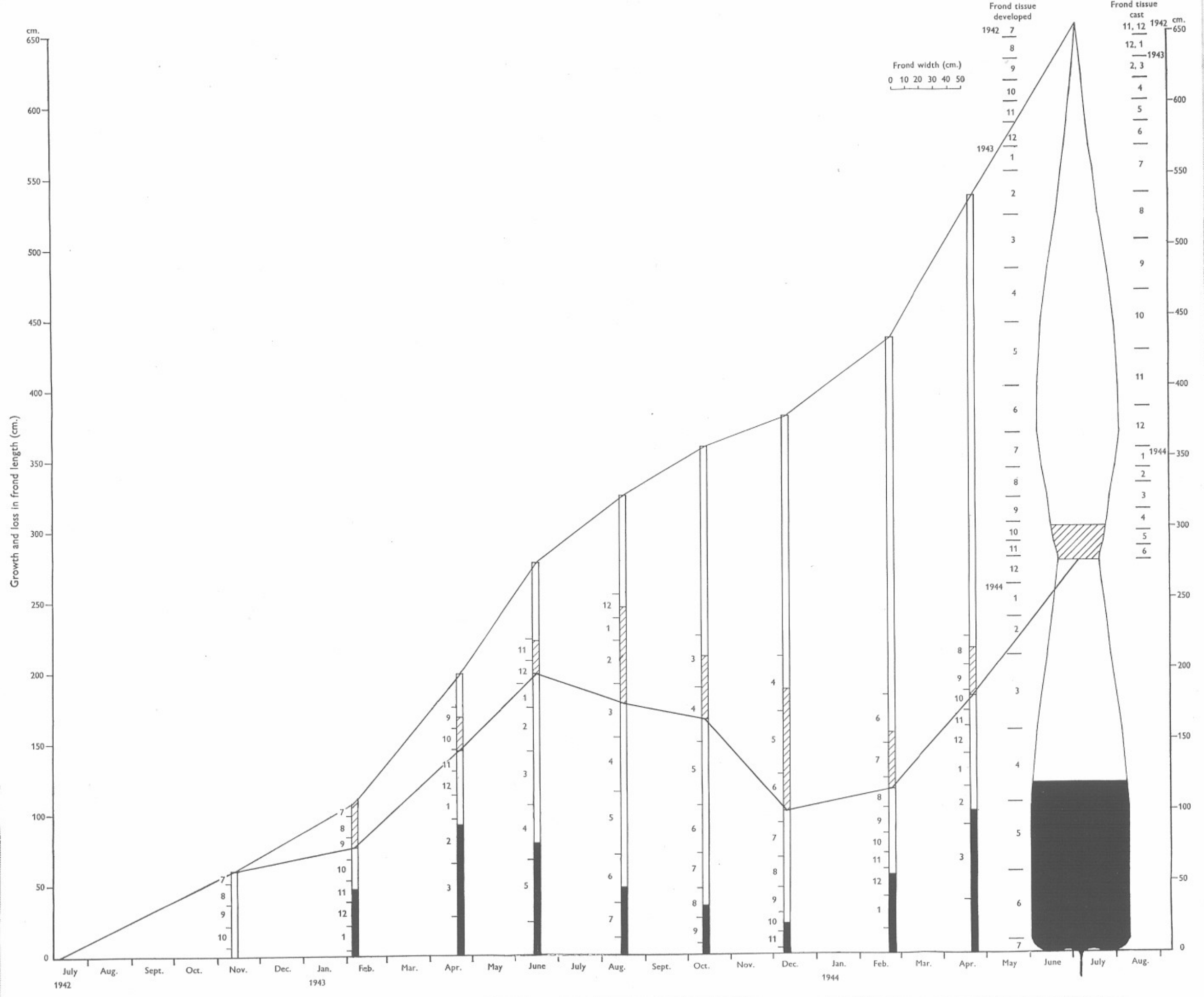


In second-year plants, however, the constriction that appears in the frond due to the slow growth in length and great reduction in the width of the tissue produced during the second period of slow growth gives the impression, when the next rapid-growth period starts, of the so-called 'new frond' formation (Pls. V, VII, X and XI). If older plants are removed or become detached at any time of the year, the younger plants beneath, after a short period, give the same impression of 'new frond' formation as do the second-year plants, owing to the more rapid growth in length and width of the new frond tissue that has developed since the removal of the older plants.

\section{Variation in Width of Frond with External Factors}

In addition to the change in frond width with age of plant and season, variation also occurs in the width of the frond tissue with difference in bathymetric zone, habitat and geographical position. The statements made earlier in connexion with the variation in the rate of frond growth in length with changes in these factors hold good also for width variation, since with an increase in the rate of frond growth in length there is, in general, a corresponding increase in frond width, and with a decrease in length-rate, a decrease in frond width.

The width of the frond increases therefore, first, with fall in level down to the upper sublittoral zone where the maximum width is reached; secondly, with the increase in the degree of shelter of the habitat; and thirdly, from the southern to the northern station. The frond is also wider in intertidal plants that remain submerged, as compared with plants which are uncovered at low tides (Pls. V-XI; Text-fig. 6). Farlow (I882) also notes that in going northward on the east coast of North America the fronds of the plants of this species become broader.

For populations growing in the intertidal zone the figures show that during the second period of rapid growth there is, in addition to the maximum increase during February and March, a secondary rise in the rate of width increase during the month of June, the rate of increase having slowed down from March to May (Text-fig. 6). This secondary rise is more pronounced in populations with emergence at low tide, since the rate of width increase slows down more from April to May; it is accompanied in these populations by a corresponding rise in the rate of frond growth in length (Text-fig. 3). Populations that remain submerged during low water in the intertidal zone also show a slight rise in the rate of width increase during June (Text-fig. 6), but they show a decrease in the rate of frond growth in length from the previous month (Text-fig. 3). In the sublittoral zone no secondary rise in the rate of frond growth in length or width has been recorded.

Tikhovskaya (1940) has shown for Laminaria saccharina plants on the Russian coast that the coefficient assimilation/respiration reaches its maximum from February to May when photosynthesis is strongest; the coefficient 
decreases with diminishing energy of photosynthesis and increasing energy of respiration during the summer months, but in the autumn (October) a slight rise in the energy of photosynthesis is recorded. From his work he concludes that the temperature and light optimum of this species are low.

It can be seen from the foregoing facts that to give figures for the frond width of a L. saccharina population in any one habitat would be of little value, since during the time of maximum width production a variation in populations in different habitats and localities of from 9.5 to $45 \mathrm{~cm}$. has been obtained on the Devon coast, and from I3 to $103 \mathrm{~cm}$. on the Argyll coast.

\section{Loss in Length}

In this species loss of frond tissue from the distal end starts when a plant is a few months old and continues throughout the life of a plant (Pls. IX-XI; Text-fig. 4). The rate of frond loss from the apex in plants over 6 months old is such that the age of the oldest frond tissue varies normally between 5 and 7 months (Pls. X, XI), but in populations growing in exposed habitats in the intertidal and sublittoral fringe zones the average age of the apical frond tissue can drop to less than 4 months (PI. IX). Frond tissue between 7 and 8 months old can survive on plants for short periods (Pls. IX, X), but in none of the populations examined has 9-months-old tissue been recorded (Text-figs. 8, 9).

Plants growing in the sublittoral zone show a more regular casting of apical frond tissue, according to the month the tissue was produced, than do plants growing in the intertidal zone (Text-figs. 3,4 ). In the former zone frond tissue developed from January to June is cast from July-August to December, and that developed from July to December between January and July (PI. XI). Since it is the frond tissue developed during the rapid-growth period of the frond that is cast from July-August to December in this zone, there is, therefore, a much heavier loss of frond tissue, both in length and weight during that period than during the period from January to June (Text-fig. 4, nos. 3, 4), and consequently the maximum frond length and weight for the year is reached between the months of June and July. There is a more definite tendency in plants in the intertidal and sublittoral fringe zones for the average age of the oldest frond tissue to vary with the season of the year, and to be slightly higher from October to March than from April to September; this retention of older frond tissue from October to March may be connected with the slowing down in the growth-rate and therefore the shorter frond length produced during the period (Pls. IX, X).

In intertidal populations also the rate of casting of frond tissue varies with the degree of exposure of the habitat. In extreme shelter the time of casting of the different months' frond tissue agrees with that found in the sublittoral zone. As the exposure of the habitat increases, the tissue produced during the months of slower growth is cast more rapidly (Pl. X; Text-fig. 4, no. 2), but the tissue developed from February to July is still cast between July and 
February. With further increase in the exposure of the habitat the tissue produced in the early part of the rapid-growth period is also cast earlier until eventually, in exposed habitats, tissue developed from January to June (rapid growth) is cast from April-May to November-December, and that developed from July to December (slow growth) is cast between December and April (Pl. IX; Text-fig. 4, no. I).

Frond loss in length from July to December is therefore still higher than from January to June in a habitat with medium exposure (Text-fig. 4, no. 2), but with greater exposure the amount of frond length lost from January to July is very little different from that lost between July and December (Textfig. 4, no. I). The maximum frond length and weight for the year in the intertidal and sublittoral fringe zones is reached at about the same time as in the sublittoral zone, or a little earlier, even when the frond loss is more evenly distributed throughout the year.

In all habitats plants in the first year of growth show some variation in the rate of frond loss due to the time of year at which they arise. On plants developed during the winter and spring sufficiently old frond tissue has been retained at the apex by the following September to November for the plants to follow the rhythm of frond loss of the older plants. In plants arising in the early part of the year the rate of growth during the slow-growth period is more rapid than in plants arising during the summer and autumn (Text-fig. 3, nos. 5, 6). Casting of apical frond tissue is more rapid, therefore, during the following spring and summer in plants developed during the summer and autumn than in plants developed during the previous winter and spring (Text-fig. 4 , nos. 3,4 ). This variation in the rate of casting of individual months' frond tissue in the first year of growth, due to the time of germination of a plant, has been shown to alter the age and the time of the year at which maturity is first reached in plants of this species. Plants over I2 months old, whatever their time of germination, follow the general rate of frond loss from the apex fairly consistently according to the habitat in which they are growing.

In this species also, whatever the time of germination, age or habitat of a plant, frond tissue produced from April-May to August-September is cast from the fronds during approximately the same period each year between October and March-April (Text-fig. 4). The variation, with time of germination of the plant and with habitat, in the time of casting of frond tissue developed between September and March-April appears to have an important bearing on the reproductive cycle of the sporophyte.

\section{GROWTH OF THE STIPE AND HoldFAST}

Before the sporeling of $L$. saccharina differentiates into stipe and frond it is attached by colourless rhizoids to the substratum. As differentiation proceeds an attachment disk develops at the base of the young stipe by cell multiplication. The first true haptera of the holdfast originate as outgrowths from this 
attachment disk, but later-formed haptera develop above the original haptera as outgrowths from the cortical tissue of the stipe.

The following zones can be recognized in a transverse section of a young stipe: a central medulla, surrounded by an inner and outer cortex, and on the outside of the cortex several layers of small cells, the outermost layer being an actively dividing meristoderm. A mucilage layer covers the meristoderm. Details of the structure of the stipe and of the development from the sporeling stage can be obtained from Drew (I9I0), Killian (I9II) and Fritsch (I945).

Many workers, in particular Foslie (I884), Setchell (I900), Killian (I9II), and Flerov \& Karsakoff (1932), have drawn attention to the variation that occurs in stipe length and in the arrangement of the haptera of the holdfast in plants of the same species of Laminaria with variation in habitat and substratum, and have concluded that neither stipe length nor holdfast arrangement can be taken as criteria for specific distinction.

There are also many references in the literature (see Fritsch, 1945) to the periodic formation of new haptera series and to the ringed appearance of the stipe in the perennial Laminariales. The 'rings' in the stipes of the Laminaria species have not been studied except by Schultz-Schultzenstein (I853) and by Printz (1926) for L. digitata Lamour. Le Jolis (1855) does, however, correlate the 'ring' formation in the stipe of $L$. cloustoni with the annual increase in thickness which, he says, corresponds with a new whorl of haptera that is produced at the same time as a new frond. The growth of the stipe and the relation of the 'rings' in the stipe to both stipe and frond growth have not so far been followed in any species of Laminaria.

In the present work the growth in length of the stipe, the increase in stipe diameter and the development of the haptera forming the holdfast have been followed in all the plants of the different $L$. saccharina populations that have been studied for the growth of the frond.

The diagrammatic longitudinal sections of the stipe and holdfast on Pl. XII, illustrate the growth of both the stipe and holdfast up to the age of approximately 2 years in two populations of $L$. saccharina, an intertidal population growing on the Devon coast (frond growth in Pls. V and X) and a sublittoral population growing on the Argyll coast (frond growth in Pls. VI, VII and XI). In these figures the central medullary zone of the stipe is indicated by two lines; the dotted areas inside the medulla represent air pockets. The stippled areas indicate the tissue of the outer cortex of the stipe that is responsible for the darker 'rings' that show in a transverse section of the stipe. The outside lines represent the surface layers of small cells including, in the younger tissue, the outermost meristoderm layer.

\section{General Rhythm in Rate of Growth}

The growth of the stipe is similar to that of the frond in that it shows considerable variation in the rate of the growth during the different seasons of 
the year. The rhythm in the rise and fall in the rate of stipe and holdfast growth during a yearly cycle follows, fairly closely, the rhythm of the primary growth in frond length.

The figures on P1. XII show that stipe growth in length and thickness is more rapid from January to June than from July to December with the maximum growth-rate between January and April and the minimum rate between September and November.

The figures show also that the formation of a new haptera series at the base of the stipe starts after the period of minimum growth, at the same time as the rise in the rate of stipe growth in length at the apex, the full haptera series completing its development by the end of the period of rapid growth. Normally, haptera series are not developed during the slow-growth period of the plant except, of course, in sporelings arising during that period, but after holdfast tissue has been eaten or damaged small secondary haptera may develop from the injured surface.

\section{Variation in Rate of Growth}

The same factors that appear responsible for the variation in frond growth seem to be responsible for the variation in the rate of stipe and holdfast growth that occurs among plants of this species, irrespective of the general rhythm in growth-rate that takes place during a yearly cycle. These factors are age and season of development of the plant, bathymetric zone, habitat and geographical position. An additional factor, the substratum, also influences the form and arrangement of the haptera of the holdfast.

\section{Effect of Age}

The influence of the age of the plant on the rate of stipe growth and the general sequence in stipe and holdfast development can be followed from the figures on Pl. XII.

After the young sporeling has differentiated into stipe and frond the primary growth in stipe length is from the apex and takes place by the cutting off of cells downwards by the formative or transition region between stipe and frond. A certain amount of secondary increase in stipe length by cell division and cell stretching occurs in the stipe tissue below the transition zone but at a diminishing rate downwards. The length of stipe tissue showing secondary increase depends on the rate of the stipe growth in length.

Increase in the diameter of the young stipe, holdfast region and haptera is due to the activity of the meristoderm or surface layer that cuts off cells inwards, thus increasing the thickness of the cortical tissue.

From July onwards, as the rate of growth of the stipe in length slows down during the period of slow growth, so also does the rate of increase in thickness, since the activity of the surface meristoderm also slows down, producing fewer cortical cells than during the period of rapid growth. The cortical cells 
produced during the period of slow growth do not reach the size of the cells formed during the rapid-growth period. The contents of these cells also appear denser, in some habitats darker brown. The denser and darker appearance may be due to the greater accumulation in the cells of physodes impregnated with fucosan, since the classical reaction of tannins was obtained with vanelin chlorohydrate. Except in the newly formed apical tissue in which the meristoderm retains its activity, there is a gradual decrease in the cell size of the cortical tissue produced until the activity of the meristoderm ceases in September or October, towards the end of the first period of minimum stipe growth.

Colour change in the surface of the stipe, holdfast region and haptera is an external indication of the change in the rate of stipe growth. When the growth-rate is rapid the surface tissue is light-coloured, but as the rate slows down the tissue darkens gradually, until at the end of the period of minimum growth, when the activity of the meristoderm ceases, the tissue is comparatively dark in colour.

After the minimum rate of stipe growth has been reached in the first slowgrowth period there is, except in the newly formed apical stipe tissue, beneath the surface layers of the stipe, holdfast region and haptera a narrow layer of

\section{Plate XII}

Growth of the stipe and holdfast in two populations of L. saccharina. A, growth throughout first 27 months of life of a spring population in the intertidal zone $(0.2 \mathrm{~m}$. above M.L.W.S.T.) on the south Devon coast, in an exposed habitat, submerged at a shallow depth at low water of mean spring tides. B, growth throughout first 24 months of life of a summer population, growing in the sublittoral zone on the Argyll coast, in a sheltered habitat at a depth of I m. below E.L.W.S.T. For explanation see text, p. 684 .

\section{Notes}

A, I, first series haptera still forming, lower haptera attached.

2 , first series haptera formed, majority attached.

3 , first series haptera attached and darkening.

4 , first series haptera dark.

5 , beginning of second series of haptera.

6 , first haptera of second series forming.

7, first haptera of second series formed, majority not attached.

8, first haptera of second series attached, further haptera forming above.

9, all haptera of second series formed, majority attached, pale in colour.

I0, all haptera of second series attached and darkening.

II, I2, second series haptera dark.

13, beginning of third series of haptera.

I4, haptera of third series forming.

I5, third series haptera formed but not attached.

I6, third series haptera attached.

B, I, first series haptera formed, majority attached, pale colour.

2 , beginning of second series of haptera, first series darkened.

3 , first haptera of second series formed, some attached, further haptera forming above.

4 , first haptera of second series attached, further haptera forming above.

5 , all haptera of second series formed, majority attached, pale in colour.

6 , all haptera of second series attached and darkening.

7,8 , second series haptera dark.

9 , beginning of third series of haptera.

Io, haptera of third series forming.

II, third series of haptera formed, majority attached, pale in colour 
small-celled cortical tissue, the smallest cells being immediately inside the innermost cells of the surface layers. This cortical layer appears denser and more compact because of the smaller cell size of the tissue, and with further stipe growth in thickness will present the appearance of a darker 'ring' in a transverse section of a stipe (P1. XIII, figs. 35, 36). This denser tissue will, in future, be referred to as 'compact' tissue or layer.

The stipes of plants that arise during the winter, spring and early summer show, after the first period of slow growth, a more definite compact layer than do the stipes of plants developed during the late summer and early autumn.

The first external indication of the start of the rise in rate of stipe and holdfast growth after the first minimum-growth period is the lightening in colour of both the apical part of the stipe below the transition zone and the base of the stipe immediately above the first haptera series. This colour change takes place from late October to early November.

At this time a layer of cells immediately outside the compact tissue starts to function as a secondary meristem. By the activity of this meristem new cortical cells, showing a radial arrangement, are produced on the outside of the compact layer. The secondary meristem first shows activity at the base of the stipe immediately above the first haptera series, and as its activity increases the original surface layers are cast off leaving the newly formed, lighter-coloured tissue at the surface. The change in colour at the base of the stipe indicates the activity of this secondary meristem and also the start of the formation of a new haptera series. At the apex the colour change is due to the more rapid rate in the growth in stipe length from the transition zone, and also to the increase in activity of the meristoderm that has remained functional in the apical part of the stipe.

By the end of December there is a further addition to the stipe length at the apex, but only a slight increase in the thickness of the new stipe tissue, whilst at the base of the stipe the first haptera of the second series can be observed as small protuberances. The activity of the secondary meristem has also spread upwards and downwards, so that a very narrow layer of new cortical tissue is present on the outside of the compact tissue part way up its length and below the new haptera down to the level of the first haptera series; the new growth frequently shows also on the outside of the proximal part of the uppermost haptera of the first series.

During January the activity of the secondary meristem continues to spread upwards on the outside of the compact tissue and the rate of stipe growth in length and thickness increases so that by February a layer of new cortical tissue is present on the outside of the whole length of the compact layer and there is an appreciable increase in the thickness of the young tissue of the stipe. At this time also the first haptera of the second series are fully grown, although the majority are not yet attached to the substratum and further haptera of the second series may be developing above those already formed. 
From late February to April there is a very rapid increase in the rate of stipe growth (Pl. XII); the increase is shown in the new length of stipe added, in the increase in the thickness of all the young stipe tissue produced since the beginning of the rapid-growth period and also in the increase in thickness of the secondary cortical layer outside the layer of compact tissue (P1. XIII, fig. 37). At this stage transverse sections of the stipe show, throughout the length of the compact layer, the new secondary cortical tissue as a lighter 'ring' or zone on the outside of the darker 'ring' of the compact layer (P1. XIII, figs. 35, 36), whereas sections of the younger stipe tissue above the level of the compact layer show no 'ring' formation in the cortical tissue (Pl. XIII, fig. 34).

In the holdfast region the first-formed haptera of the second series are attached and further haptera are forming above them. The increased activity of the secondary meristem in the holdfast region below the level of the second haptera series is shown by the increase in width of the layer of secondary light-coloured cortical tissue on the outside of the compact layer of part of the holdfast region and on the outside of the proximal parts of the upper haptera of the first series. At this stage transverse sections of the uppermost haptera of the first series, taken near the point of origin from the stipe, show 'ring' formation (PI. XIII, fig. 45).

Plate XIII. Laminaria saccharina (L.) Lamour.

Photographs of sections of the stipe and holdfast. Figs. 34 and 35 are sections of the stipe of a plant from the same habitat as the plants illustrated on Pl. V. Figs. 36-45 are sections of the stipes of plants from the same blocks as the plants illustrated on Pls. VI and VII. Natural size.

Fig. 34. T.S. of stipe of I2-months-old plant taken from the stipe length produced during the second period of rapid growth. 28. iii. I944.

Fig. 35. T.S. of stipe of I2-months-old plant taken from half-way up the length of the first compact layer. 28. iii. I944.

Fig. 36. T.S. of stipe of ro-months-old plant taken from half-way up the length of the first compact layer. 22. iv. I943.

Fig. 37. L.S. of base of the stipe and the holdfast of a ro-months-old plant. 22. iv. I943.

Fig. 38. T.S. of stipe of I8-months-old plant taken from near the apex. Io. xii. I943. See text, p. 69I, for explanation of Figs. 38-4I.

Fig. 39. T.S. of stipe of I8-months-old plant taken from the middle of the stipe length produced during the first rapid-growth period-medulla broken down. IO. xii. I943.

Fig. 40. T.S. of stipe of 18 -months-old plant taken from near the top of the length of the first compact layer. I0. xii. I943.

Fig. 4I. T.S. of stipe of I8-months-old plant taken from half-way up the length of the first compact layer. Io. xii. I943.

Fig. 42. T.S. of stipe of 24 -months-old plant taken near the top of the stipe length added during the first rapid-growth period. 6. vii. I944.

Fig. 43. T.S. of stipe of I8-months-old plant at the end of the second slow-growth period. Section taken near top of first compact layer. IO. xii. 1943 .

Fig. 44. T.S. of stipe of 18 -months-old plant at the end of the second slow-growth period. Section taken half-way up length of first compact layer. IO. xii. I943.

Fig. 45. L.S. of stipe and holdfast of 18 -months-old plant at the end of the second slow-growth period showing the compact layer formed in the haptera during the first slow-growth period. I0. xii. I943. 


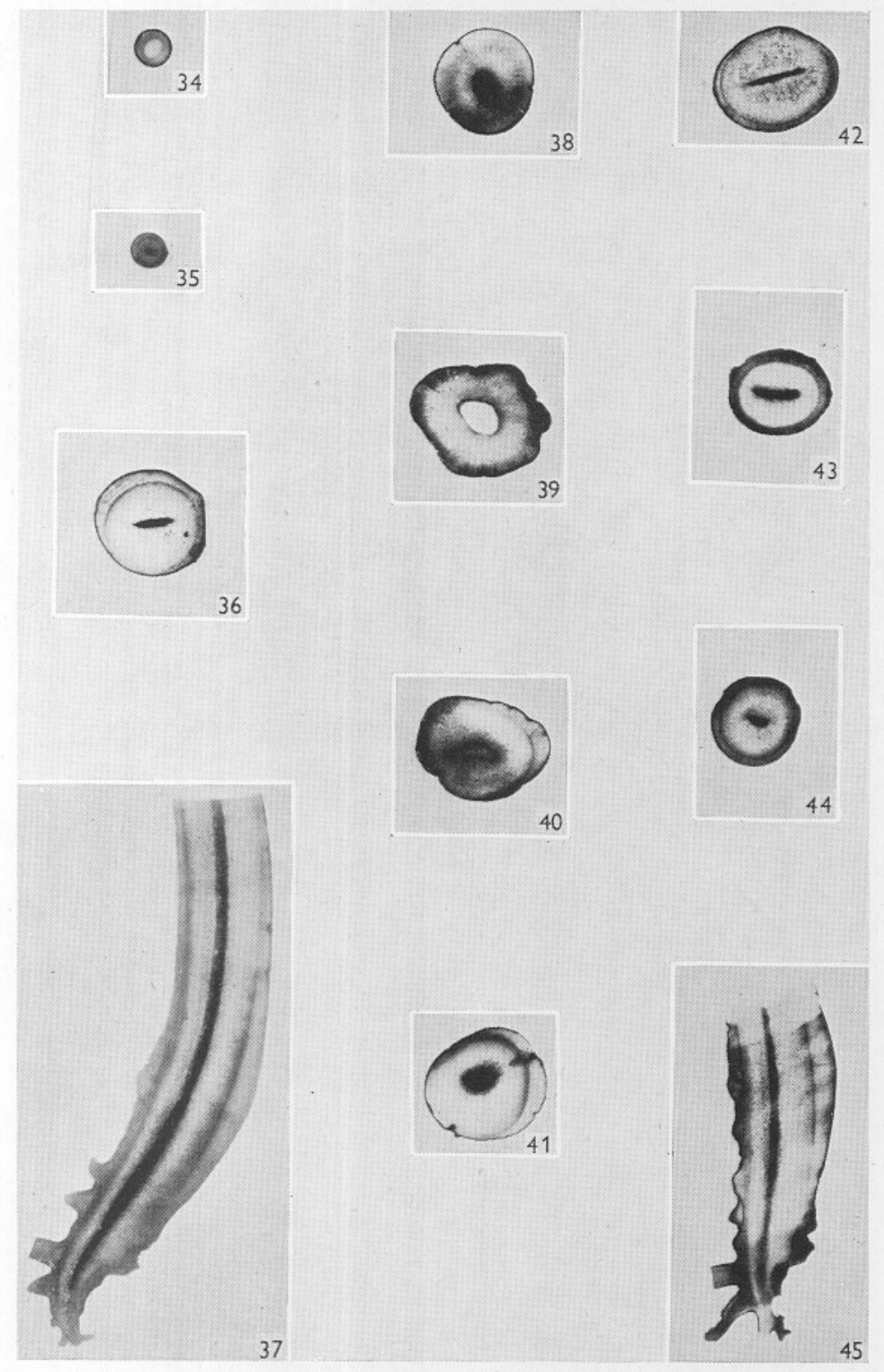

Figs. 34-45. 
Growth in length and thickness of the stipe continues during May and June, but at a slower rate than during March and April. By the end of June all the haptera of the second series are formed and the majority are attached to the substratum. The haptera of the second series are larger than those of the first series. Externally the stipe and second series of haptera are still light in colour showing that the surface meristoderm of the younger stipe tissue and the secondary meristem of the older stipe tissue are still producing rapidly growing tissue.

As the growth-rate slows down from July onwards, in the second slowgrowth period of a plant, a second compact layer is formed on the outside of the stipe, holdfast region and haptera (PI. XIII, figs. 43-45). The minimum growth-rate is reached between September and October, but in the second slow-growth period the rate of growth does not start to rise again until the middle or end of December, approximately I month later than in the first period of slow growth.

During the rapid-growth period following the second period of slow growth in the life of a plant (second or third depending on time of germination of the plant), although a cell layer on the outside of the second compact layer of the stipe again functions as a secondary meristem, it is not so active as the secondary meristem of the previous rapid-growth period. In this rapid-growth period new light-coloured tissue is formed only on the outside of the second compact layer at and near the base of the stipe above the second series of haptera (Pl. XII). The third haptera series develops from this tissue, but the haptera are fewer in number and of a smaller size than those developed during the previous rapid-growth period.

From just above the base of the stipe up to the level of the top of the first compact layer there is very little activity of the secondary meristem, and therefore during this rapid-growth period there is only a slight increase in thickness of this region of the stipe. The tissue formed by the secondary meristem in this region of the stipe is small-celled and in most plants cannot be distinguished from the tissue of the second compact layer, since all the cells show a radial arrangement. The surface of this part of the stipe, therefore, remains dark in colour.

In the region of the stipe in which the meristoderm ceased to function at the end of the second slow-growth period, that is, the stipe length from the level of the top of the first compact layer to the level of the top of the second compact layer, the new secondary meristem is more active than in the region of the first compact layer. Although the secondary cortical tissue produced by this secondary meristem on the outside of the second compact layer is rather small-celled tissue and therefore appears fairly dense, it can be distinguished from the tissue of the second compact layer by the radial arrangement of the cells (P1. XIII, fig. 42). The original surface layers, including the meristoderm, are cast from this region of the stipe, and therefore externally this region can be 
distinguished from the older stipe length by the lighter colour of the surface tissues. The colour of this region is not so light, however, as the new stipe length that has developed during this rapid-growth period. Externally three colour zones can, therefore, be distinguished in the stipe at the end of the rapid-growth period following the second period of slow growth.

During the third slow-growth period the rate of growth in both stipe length and thickness is extremely slow, so slow in some plants that it is hardly discernible. The third compact layer that forms on the outside of the stipe and on the third series of haptera is therefore very narrow, and in many plants can be recognized only at the base and apex of the stipe.

The method of stipe growth in this species described above and figured on Pl. XII shows that, whatever the habitat, the approximate age of a $L$. saccharina plant can be assessed from an examination of the holdfast region (thick longitudinal section), since at this level the number of lighter and darker growth zones indicates the number of rapid-and slow-growth periods through which a plant has survived. The approximate length of stipe tissue formed during the first, second and third rapid- and slow-growth periods can also be obtained from a longitudinal section of the stipe. In the present work no evidence has been obtained from stipe and holdfast examinations to show that plants of this species persist on the British coast beyond the third period of slow growth.

The following points emerge from the observations on the growth of the stipe and holdfast in different-aged plants of this species. In plants arising early in the year the stipe length produced during the second period of rapid and slow growth is often equal to and seldom much less than that produced during the first period, but the length of stipe produced during the third period is always shorter than that produced during either of the two previous rapid- and slow-growth periods. The diameter of the stipe tissue produced during the second rapid- and slow-growth period is, however, greater than that produced during either the first or the third period of rapid and slow growth. Haptera development and secondary increase in thickness of the stipe also reach their maximum during the second period of rapid growth.

In plants arising later in the year, that is, during the slow-growth period of the species, the stipe length produced during the first slow- and rapid-growth period is always far greater than that produced during the second period. These plants go from the shore before the third period of rapid growth. The diameter of the stipe tissue produced during the first rapid-growth period is equal to if not greater than that produced during the second period. Haptera development and secondary increase in stipe thickness reach their maximum during the first period of rapid growth; thus the time of the maximum differs from that found in plants arising during the rapid-growth period of the species.

The stipes of the summer- and autumn-developed plants grow so rapidly in length and thickness during the first rapid-growth period that the development of the central medullary tissue does not keep pace with that of the cortical 
tissue and the medulla therefore becomes filled with air pockets (PI. XII, B). In some plants the medulla breaks down completely in the rapidly growing part of the stipe and this part of the stipe becomes hollow; it also remains hollow throughout the life of the plant.

Pl. XIII, figs. 38-4I, show transverse sections of the stipe of a summerdeveloped plant at the end of the second period of slow growth. From the base upwards the first section (fig. 4I) is taken from halfway up the length of the first compact layer and the second section (fig. 40) from near the top of the first compact layer. The third section (fig. 39) is taken from the middle of the stipe length produced during the first rapid-growth period. This part of the stipe is hollow because of the complete breakdown of the medullary tissue. The fourth section (fig. 38) is taken from near the top of the stipe and is through the young stipe tissue in which the meristoderm has not ceased to function. The zone of less dense tissue on the outside indicates the beginning of the increase in activity of the meristoderm.

These summer-developed plants in which the apical part of the stipe becomes hollow agree with the description given by Børgesen (1903) for the species Laminaria faeroensis.

The sequence of the variation in the rate of growth of the stipe in plants arising during the rapid-growth period agrees fairly closely with the sequence that occurs in the rate of growth of the frond with change in age of the plant. Although the length of stipe tissue produced during the first rapid-growth period may be greater than the length produced during the second rapidgrowth period, the actual amount of stipe tissue added, that is, in length, thickness, secondary thickness and haptera, is greater during the second rapid-growth period than during the first. As in the frond growth, the rate of stipe and holdfast growth during the third rapid-growth period varies considerably in populations growing in different habitats, but it is always less than the rate of growth of the stipe and holdfast during the second rapidgrowth period. During the slow-growth periods the sequence in the rate of stipe growth is also in accord with that found in the frond except that the minimum rate is reached slightly earlier than in the frond.

For plants arising during the slow-growth period it has been shown that the growth-rate of the frond is higher during the first rapid-growth period than in plants arising during the early part of the year. The rate of stipe growth is also higher during the first rapid-growth period in plants arising during the slowgrowth period, but unlike the rate of growth of the frond which increases during the second rapid-growth period, the rate of stipe growth is not so great during the second as during the first period of rapid growth.

\section{Effect of Habitat}

Habitat influences the rate of growth of the stipe and holdfast as it does the rate of growth of the frond (Pls. V-VIII). As in the frond the general 
indications are that the rate of stipe growth increases with the degree of shelter of the habitat, with submergence of the plants as against emergence at low water, and with fall in shore-level down to the upper sublittoral zone. The maximum rate of stipe growth is reached $\mathrm{I}-4 \mathrm{~m}$. below extreme low water of spring tides.

At and above the level of E.L.w.S.T. the growth in length of the stipe never reaches a $0.3 \mathrm{~cm}$. increase a day during the rapid-growth period, whereas in the sublittoral zone the daily increase in stipe length can reach a figure of $0.5 \mathrm{~cm}$. The measurements of stipes of plants of this species growing on the Devon and Argyll coast show that the range of stipe size is very great. On exposed shores in the intertidal zone in habitats that dry out at low water the stipe of a plant at the end of the second slow-growth period may be less than IO $\mathrm{cm}$. long with a diameter of $0.5 \mathrm{~cm}$., while plants of the same age growing in the sublittoral zone on sheltered coasts may have a stipe length of up to $130 \mathrm{~cm}$. with a diameter of $\mathrm{I} \cdot 9 \mathrm{~cm}$.

The tissue of the slow-growing stipes, particularly that formed during the slow-growth periods, is much darker in colour than the tissue of the more rapidly growing stipes. This colour variation of the stipe tissue in plants growing in different habitats may be due, partly to the smaller cell size of the tissue in slow-growing stipes, and partly to variation in chemical composition of the stipe tissue of plants growing at different levels on the shore. Black (1948) working on Laminaria spp., Russell-Wells (1932) and Haas \& Hill(I933) working on Laminaria and other genera have shown that there is a variation in the chemical composition with the degree of emergence and the depth of immersion of the plants.

The variability in frond development during the third period of rapid growth in populations of this species growing in different habitats has been connected with depth of submergence of the plants. Stipe and holdfast development during the third period of rapid growth also shows variability with difference in depth of submergence of the plants. In populations growing in the intertidal zone in habitats that dry out at low water of mean spring tides growth of the stipe and holdfast practically ceases early in the second period of slow growth. The third haptera series, therefore, is not produced, and on exposed coasts the plants fail to survive the third period of rapid growth.

In populations growing at the same level in the intertidal zone but in pools there is usually a slight increase in stipe length during the third period of rapid growth and a third haptera series is also formed, but the haptera are small and very few in number. In populations growing in the upper part of the sublittoral zone, however, there is, during the third period of rapid growth, an appreciable increase in stipe length and a fuller development of the third haptera series.

In this species the form of the holdfast depends on the nature of the substratum on which the plant is growing. The variation in form that can occur 
with variation in the character of the ground has been dealt with in detail by Flerov \& Karsakoff (1932). In general, the two extremes of form occur on rock and on soft silty ground. On rock the holdfast is compact with the haptera thick and only slightly branched (Pls. V; VIII, figs. 26, 29), while on soft silty ground the holdfast is much less compact and the haptera are thinner, longer and very copiously branched (Pl. VIII, fig. 33). All gradations between the two extreme forms can be obtained on different types of ground.

\section{Geographical Variation}

The figures for the growth of the stipe and holdfast of this species on the coasts of Devon and Argyll suggest that the difference in the growth of the stipe and holdfast in the two localities might also be correlated with difference in latitude. There is a higher rate of growth at the more northern station, and only at this station is the stipe growth so rapid that the medulla breaks down completely, leaving the stipe hollow. At this station also the maximum rate of stipe growth is reached in April and the minimum rate in October, while at the more southern station the maximum rate is reached in March and the minimum rate in September, approximately one month earlier than at the more northern station.

The results of the work on the growth of the sporophyte of $L$. saccharina on the Devon and Argyll coasts have shown that there is, within the plant itself, some dominant factor controlling the rhythm of its development, but that there are also factors external to the plant that may modify, very considerably, the morphological and anatomical character of the species.

Information from localities round the greater part of the British coast is still needed before a full knowledge of the variation in form of this species with change in its geographical position on the British coast can be assessed.

Records of the growth and behaviour of the species throughout its total range are also necessary before the full influence of latitude, direct or indirect, on the behaviour of the species can be understood, since, according to Wimpenny (I94I), one algal group, the Dinophyceae, shows an increase in size with increase in latitude, whilst in another group, the Bacillariophyceae, the marine pelagic forms decrease in size with increase in latitude.

\section{REPRODUCTION IN THE SPOROPHYTE}

In the literature very little information is available on the reproductive period of the sporophyte of $L$. saccharina on different parts of the British coast. It is recorded by Rees (1928) for the Aberystwyth and Gower coast as occurring from October to early April; these records are for plants growing in the intertidal zones in habitats that dry out during low water of spring tides. During 
the period $1923-27$ he found no plants fruiting from late April to September; the main fruiting was from November to the end of February, the peak being reached during either January or February. Harries (1932) states that during 1929-30 reproduction in $L$. saccharina at Aberystwyth started early in November and ended early in March (Text-fig. 7, no. $2 b$ ), but in a less exposed region, St Davids, reproduction started a month earlier than at Aberystwyth. Knight \& Parke (I93I) record the production of reproductive tissue during all seasons of the year on plants growing on the coast of the Isle of Man.

On the French coast Sauvageau (I9I8) found reproductive tissue on adult plants at all times of the year, whilst Børgesen (1903), during the period from May to November, found fructifying specimens in the Faeröes only during the months of June and July. On the Norwegian coast, in the Trondheim Fjord, Printz (1926) found reproducing plants in the middle of May and at the end of September and concludes that the sporogenous tissue becomes detached gradually from the frond during the autumn, whereas further north, on the East-Finmarken coast, according to Foslie (I890), reproduction occurs in the winter or early in the spring. For the Arctic, Kjellman (1883) states that on the coast of the Polar Sea sublittoral varieties only bear zoosporangia during July, August and early September, the varieties at and near low-water mark being sterile during this period. According to Kireeva \& Schapova (1933, 1938) reproduction of this species on the Murman coast starts in July, reaches a maximum early in August and finishes at the end of August.

The present work has shown that on the coast of Devon and Argyll plants of this species can be found bearing reproductive tissue during all months of the year; in all populations, however, the percentage of reproducing plants is highest between the months of October and March (Text-fig. 7).

Contrary to the findings of Kireeva \& Schapova (1933, 1938), who state that L. saccharina does not reach maturity on the Murman coast until the third year of growth, this work has shown that on the British coast reproductive tissue first develops on the fronds when the plants are from 8 to I2 months old (P1. V, figs. 2, 3; P1. VIII, fig. 26). Plants that develop during the early part of the year can start to bear reproductive tissue when they are 8-9 months old, but plants developed later in the year do not form reproductive tissue until they are nearly I year old. The plants, therefore, that start life during the rapidgrowth period of the species reach maturity approximately 4 months earlier than do plants that start life during the period of slow growth.

\section{Development of Reproductive Tissue}

For reproductive tissue to develop on a frond of a $L$. saccharina plant the distal tissue present on the frond must be in at least the sixth month of growth. Once reproductive tissue is present on frond tissue in the sixth month of growth, it can arise also on frond tissue in the fifth month of growth. If how- 
Jan. Feb. Mar. Apr. May June July Aug. Sept. Oct. Nov, Dec. Jan. Feb. Mar. Apr. May June July Aug. Sept. Oct. Nov. Dec. Jan. Feb. Mar. Apr. May June July

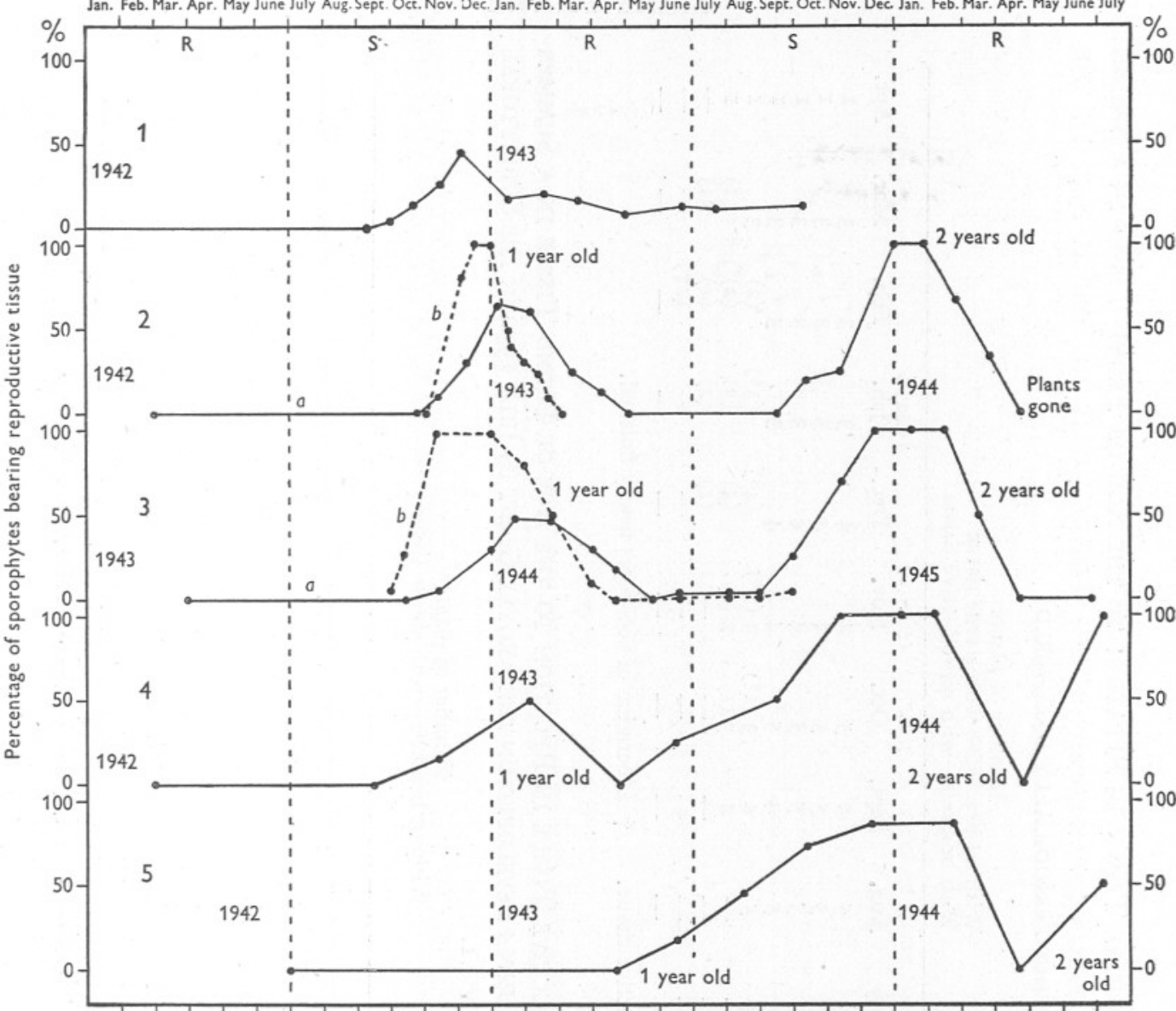

Jan. Feb. Mar. Apr. May June July Aug. Sept. Oct. Nov. Dec. Jan. Feb. Mar. Apr. May June July Aug. Sept. Oct. Nov. Dec. Jan. Feb. Mar. Apr. May June duly

Text-fig. 7. Periodicity of reproduction in different populations of $L$. saccharina, showing the variation with age, time of germination, habitat and locality. The graphs start at the month when the plants germinated (except graphs $\mathrm{I}, 2 b$ and $3 b$ ).

(I) Population on floating raft. Plymouth Sound, Devon, sheltered habitat, shallow submergence permanent. First sporophytes germinated December I94I-January I 942 and new sporophytes added each succeeding month; all sporophytes, including sporelings, counted in samples examined for percentage reproduction in population.

(2a) Spring population, I942. Devon, exposed shore, intertidal zone, above M.L.W.S.T. (thus periodically uncovered).

(2b) Normal population. Aberystwyth, 1929-30. Figures given by Harries (1932).

(3a) Spring population, I943. Devon, exposed shore, intertidal zone (above M.L.W.S.T.), in pools (thus never uncovered).

(3b) Normal population, 1943-44 (chiefly plants in second and third year of growth-very few first-year plants). Devon, exposed shore, intertidal zone (above M.L.W.S.T.), in pools.

(4) Spring population, I942. Argyll, sheltered shore, sublittoral zone, at depth of I m. below E.L.W.S.T.

(5) Summer population, 1942. Argyll, sheltered shore, sublittoral zone, at depth of I m. below E.L.W.S.T.

$\mathrm{R}$, rapid-growth period. $\mathrm{S}$, slow-growth period. 
Table Vi. The Production of Reproductive Tissue in Relation to the Age of Frond Tissue in a Spring Population of LAMiNARIA SACCHARINA DEVEloped ON THE Devon CoAST IN MaRCH I942 IN THE INTERTIDAL ZONE, ABOVE M.L.W.S.T. (THUS PERIODICALLY UNCOVERED)

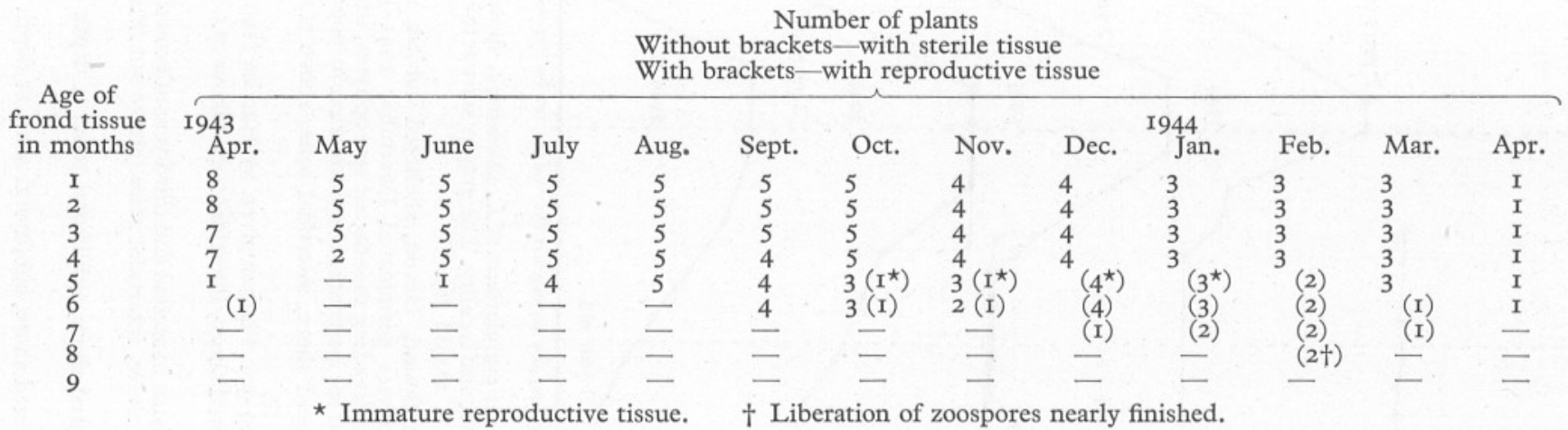

Table ViI. The Production of Reproductive Tissue in Relation to the Age of Frond Tissue in a Summer

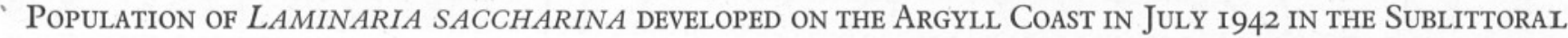
ZONE AT A DEPTH OF I m. BELOW E.L.W.S.T.

Number of plants

Without brackets-with sterile tissue

With brackets-with reproductive tissue

\begin{tabular}{|c|c|c|c|c|c|c|c|c|c|c|}
\hline \multirow{2}{*}{$\begin{array}{l}\text { Age of } \\
\text { frond tissue } \\
\text { in months }\end{array}$} & \multicolumn{10}{|c|}{ 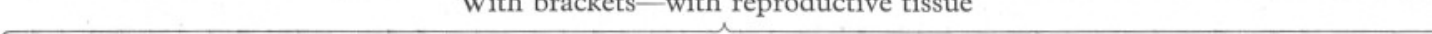 } \\
\hline & $\begin{array}{l}\text { I942 } \\
\text { Nov. }\end{array}$ & $\begin{array}{c}\text { I943 } \\
\text { Feb. }\end{array}$ & Apr. & June & Aug. & Oct. & Dec. & $\begin{array}{c}\text { I944 } \\
\text { Feb. }\end{array}$ & Apr. & June \\
\hline I & 25 & 20 & 20 & 20 & II & II & Io & 7 & 5 & 4 \\
\hline 2 & 25 & 20 & 20 & 20 & II & II & Io & 7 & 5 & 4 \\
\hline 3 & 25 & 20 & 20 & 20 & II & II & Io & 7 & 5 & 4 \\
\hline 4 & 25 & 20 & 20 & 20 & II & II & Io & 7 & & 4 \\
\hline 5 & 25 & 20 & I4 & 20 & $5\left(5^{\star}\right)$ & $3\left(7^{\star}\right)$ & $\left(9^{\star}\right)$ & $\left(6^{\star}\right)$ & 5 & 4 \\
\hline 6 & - & 8 & 12 & I2 $\left(4^{\star}\right)$ & $3(5)$ & $3(5)$ & (9) & (6) & & I $\left(3^{\star}\right)$ \\
\hline 7 & - & - & - & (4) & (2) & (7) & (8) & (5) & $(3 t)$ & (3) \\
\hline 8 & - & - & - & - & - & $(2 \dagger)$ & $(2 \dagger)$ & - & - & - \\
\hline 9 & 一 & 一 & - & - & - & 一 & - & 一 & - & 一 \\
\hline
\end{tabular}


ever it arises on frond tissue in the fifth month of growth it does not usually mature until the beginning of the next month (Tables VI-VIII; Textfigs. 8, 9). The evidence available indicates that reproductive tissue is produced only on frond tissue that is approaching or has reached final expansion. Since considerable expansion occurs during the spring months in frond tissue in the fifth and sixth month of growth, during the period of maximum increase in frond length above the $10 \mathrm{~cm}$. level, production of reproductive tissue during this period is at a minimum.

It takes from I4 to $2 \mathrm{I}$ days for reproductive tissue to develop and reach maturity in this species. There is no perceptible variation in the time taken for reproductive tissue to develop with differences in the age and habitat of

Table VIII. The Production of Reproductive Tissue in Relation to the Age of Frond Tissue in a Spring Population of Laminaria SACCHARINA DEVELOPED ON THE DeVON COAST IN APRIL I943 IN THE INTERTIDAL ZONE (ABOVE M.L.W.S.T.) IN POOLS

\begin{tabular}{|c|c|c|c|c|c|c|c|}
\hline \multirow{2}{*}{$\begin{array}{l}\text { Age of } \\
\text { frond tissue } \\
\text { in months }\end{array}$} & \multicolumn{7}{|c|}{$\begin{array}{l}\text { Number of plants } \\
\text { Without brackets - with sterile tissue } \\
\text { With brackets - with reproductive tissue }\end{array}$} \\
\hline & $\begin{array}{l}\text { I944 } \\
\text { June }\end{array}$ & July & Aug. & Sept. & $\begin{array}{c}\text { I945 } \\
\text { Jan. }\end{array}$ & Feb. & June \\
\hline I & 34 & 32 & 29 & 24 & 5 & 4 & 3 \\
\hline 2 & 33 & 30 & 26 & 24 & 5 & 4 & 3 \\
\hline 3 & 32 & 26 & 23 & 19 & 5 & 4 & 3 \\
\hline 4 & 27 & 24 & 22 & I9 & & 4 & 3 \\
\hline 5 & 23 & 24 & 21 & I3 $\left(6^{\star}\right)$ & $\left(5^{\star}\right)$ & $\left(4^{\star}\right)$ & 3 \\
\hline 6 & $3(\mathrm{I})$ & $3(3)$ & I (I) & $8(6)$ & (5) & (4) & - \\
\hline 78 & 二 & 二 & - & (2) & (3) & (3) & - \\
\hline $\begin{array}{l}8 \\
9\end{array}$ & - & - & 二 & Z & $-(2 t)$ & $-(\mathrm{I} \dagger)$ & E \\
\hline * Immat & 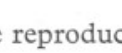 & tissu & $+I$ & 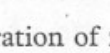 & & rly fit & \\
\hline
\end{tabular}

the plant, or with the season of the year. Once reproductive tissue has reached maturity it can continue to liberate zoospores for $2-3$ months if the frond tissue bearing it is retained by the plant.

When reproductive tissue first reaches maturity it bears approximately $\mathrm{I}, 000,000$ ripe sporangia per $\mathrm{cm} .{ }^{2}$ of frond surface. Sporangium initial cells and immature sporangia are not included in the above figure. A fortnight to a month after the first liberation of zoospores, the number of ripe sporangia is about 500,000 per $\mathrm{cm} .^{2}$ of frond surface. During the second and third months after the first liberation of zoospores there is a further drop in the number of ripe sporangia present on the reproductive tissue, although new sporangium initial cells continue to develop and mature, frequently inside the walls of sporangia from which the zoospores have been liberated. Kireeva \& Schapova (1938) give 562,500 as the number of sporangia per cm. ${ }^{2}$ of frond surface on plants of this species growing on the Murman coast. 
The number of zoospores produced by one sporangium is 32 ; this figure agrees with that given by Schreiber (193I) for plants growing at Heligoland, but not with that given by Kireeva \& Schapova (1938) who state that the sporangia developed on plants on the Murman coast produce 64 zoospores.

Drew (I9I0), working at the Plymouth Laboratory, obtained 2,000,000 gametophytes from I sq. in. of reproductive area of the frond, whilst from Kireeva's and Schapova's (1938) figures it can be estimated that $36,000,000$ zoospores are produced per $\mathrm{cm} .{ }^{2}$ of frond surface of plants on the Murman coast. The above figures, however, are the numbers of zoospores, or the gametophytes developed from the zoospores, produced by the reproductive tissue on the frond at one time.

If reproductive tissue is retained for a sufficiently long period on the frond, it develops successive crops of sporangia. It has been estimated that if reproductive tissue can persist on the frond for 3 months after it first reaches maturity, $\mathrm{I} \mathrm{cm} .^{2}$ of frond surface bearing reproductive tissue can produce up to $2,000,000$ sporangia. This means that if reproductive tissue is retained on a plant until the frond tissue bearing it is in the eighth month of growth, $\mathrm{I} \mathrm{cm}{ }^{2}$ of frond surface can liberate $64,000,000$ zoospores over a period of 3 months. It is, however, only for a short period during the year that frond tissue in the eighth month of growth is retained by plants of this species (Tables VI-VIII). In the intertidal and sublittoral fringe zones frond tissue in the seventh month of growth also does not persist on the plants for more than 6 months of the year, frequently for a much shorter period (Tables VI, VIII; Text-fig. 8).

There is, therefore, a certain wastage of potential reproductive products in plants of this species, particularly in plants growing in the intertidal and sublittoral fringe zones. The wastage, however, is not more than about $25 \%$ of the total number of zoospores that could have been produced if the frond tissue had survived beyond the age of 6 months, since the number of sporangia developed diminish rapidly with each successive crop that is produced. On any frond tissue $50 \%$ of the total number of zoospores that can be produced during 3 months are released when the tissue first reaches maturity in the sixth month of growth and another $25 \%$ by the end of the sixth month or early in the seventh month, leaving only $25 \%$ of the total number that can be produced by the tissue for release during the seventh and eighth months of frond growth.

As frond tissue formed during any month of the year has to reach a certain age and certain stage in development before it can bear reproductive tissue, the frond tissue produced during any one month of the year by all plants of this species will bear reproductive tissue at approximately the same time of the year if it persists on the plants (Text-figs. 8, 9). At any time of the year, therefore, the proportion of the frond length bearing reproductive tissue in plants of this species is obviously dependent on the rate of growth in length of the particular frond, the rate of casting of its distal frond tissue, and the 
particular month's or months' frond tissue that is bearing the reproductive tissue (see Text-figs. 8, 9 with figures for frond length in $\mathrm{cm}$. at side of

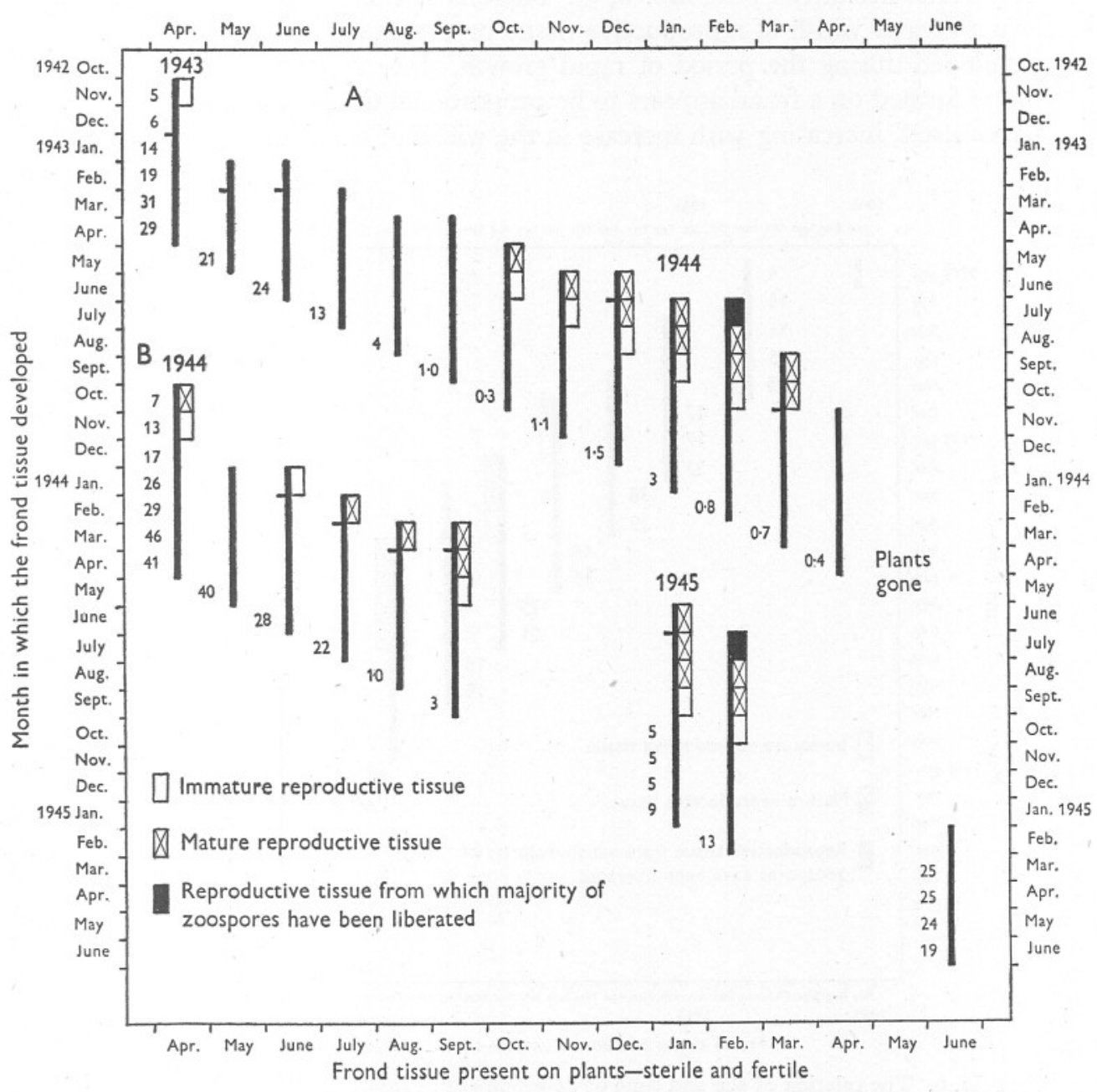

Text-fig. 8. The relation of age and time of development of frond tissue to the production of reproductive tissue on the fronds of two intertidal spring populations of L. saccharina. The black column represents frond tissue present on plants; the maximum amount is given by the full length of the line, the average amount marked on the left by a short protruding line. Those parts of the frond which have reproductive tissue are clearly marked by the rectangles projecting on the right side of the column. Figures at the side of the columns indicate the length of frond tissue (in $\mathrm{cm}$.) developed during that month. Devon, exposed shore, intertidal zone; A, above M.L.W.S.T. (from I4th to 25 th month of life); B, at same level in pools (from I3th to $27^{\text {th }}$ month of life).

columns). Throughout a yearly cycle, the frond tissue formed during the period of rapid growth will produce a greater proportion of reproductive tissue, and 
therefore a greater number of zoospores, than the frond tissue formed during the period of slow growth, providing these tissues persist on the plant until they reach maturity (Text-figs. 8, 9). There is not only a greater length but also a greater width of reproductive tissue produced on frond tissue that has developed during the period of rapid growth, since the width of sporangial tissue formed on a frond appears to be proportional to the width of the frond tissue itself, increasing with increase in the width of the frond.

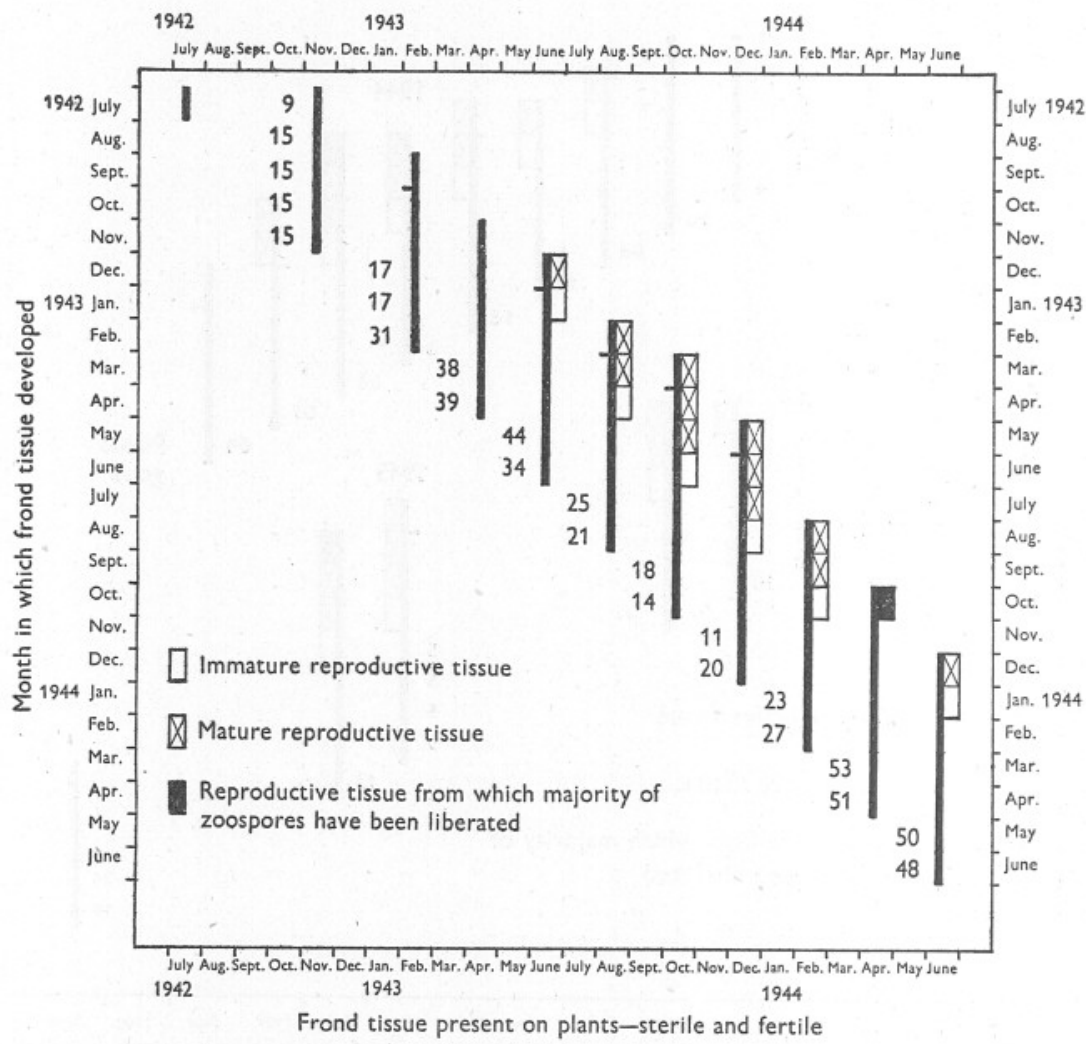

Text-fig. 9. The relation of age and time of development of frond tissue to the production of reproductive tissue on the fronds in a sublittoral summer population of $L$. saccharina, growing on the Argyll coast in a sheltered habitat at a depth of I m. below E.L.W.S.T. Explanation as in Text-fig. 8.

In any habitat, therefore, the maximum production of reproductive tissue takes place in a second-year plant since the peak of frond growth in length and width is reached during the second year of growth. There is also variation in the amount of reproductive tissue produced by plants growing in different habitats and at different latitudes, the area of reproductive tissue produced by the plants increasing with decrease in level on the shore, with increase in the 
shelter of the habitat, and with increase in the latitude. Considerable variation is, therefore, to be found in the shape, area and position of the reproductive tissue that develops on the fronds of plants of this species (Pls. V-VIII).

\section{PERIODICITY OF REPRODUCTION}

As the age of the distal frond tissue on a first-year plant is controlled more by the time of development of the plant and the resulting initial rate of growth during the first 6 months than by factors external to the plant, the time of the year that reproductive tissue first develops on a plant is controlled also by the time of the year the plant starts to develop.

In a plant over I2 months old, however, the age of the distal frond tissue depends on the degree of exposure or protection afforded to the plant by the habitat in which it develops. The period during which a plant can produce reproductive tissue depends, therefore, on the nature of the habitat in which the plant is growing; the reproductive period is extended in sheltered habitats and curtailed in exposed habitats.

Throughout a yearly cycle, therefore, the duration of the reproductive period in any population of $L$. saccharina, and the percentage of that population bearing reproductive tissue during the reproductive period, depend on two factors, the type of habitat in which the population is growing and the numbers of the different season and year groups making up the population.

As frond tissue developed from April-May to August-September is cast in all plants of this species between the months from October to March-April, and as the age of the oldest frond tissue in all plants is higher from October to March than from April to September, the maximum production of reproductive tissue will take place in all populations, whatever the type of habitat, from October to March on the frond tissue developed from approximately April to September (Text-fig. 7). It is, therefore, the extension of the reproductive period of a population beyond October to March that is controlled by the two factors, the habitat and the components of a population.

Earlier in this paper, production, longevity and depopulation-rate of the sporophytes were related to bathymetric zone and degree of exposure of the habitat, therefore the components of any population, at any season, depend also on the habitat factor. The nature of the habitat of a population is therefore the controlling factor for the production, or lack of production, of reproductive tissue on the plants during the period from April to September.

The nature and locality of the shore examined by different workers is no doubt responsible for the apparent discrepancy given in the literature in the records of the time of reproduction of this species.

On the British coast, throughout a yearly cycle, the reproductive period of this species is shortest (October to early April) in populations growing on exposed shores in intertidal habitats that dry out at low water of mean spring tides (Text-fig. 7 , nos. $2 a, b$ ). 
In these habitats, the persistence of just the spring sporophytes (Table III) that first reach maturity during the autumn and winter following their germination (Text-fig. 7, no. $2 a$ ) and the rapid casting of the frond tissue from April to September in the second-year spring plants (Pl. IX; Textfig. $8 \mathrm{~A}$ ), so that frond tissue sufficiently old to bear reproductive tissue is not retained by the plants (Table VI; Text-fig. 8A), account for the short duration of the reproductive period.

On exposed shores, but in the populations in the pools and in the sublittoral zone, although the main reproductive period is still October to early April (Text-fig. 7 , no. $3 a, b$ ), it is more extended (June to April), as a very small percentage of the populations in these habitats bears reproductive tissue from June to September (Text-figs. 7 , no. $3 a, b$; 8B). The extension of the reproductive period of the populations growing in these habitats is due partly to the persistence of small numbers of early summer sporophytes in the pools and of small numbers of summer and autumn sporophytes in the sublittoral zone (Table III) that first reach maturity during the summer and autumn following their germination; it is due equally to the retention of frond tissue in at least the sixth month of growth by a small percentage of the second-year spring plants (Table VIII; Text-fig. 8B).

In this species the reproductive period is longest in populations growing on sheltered parts of the coast in both intertidal and sublittoral-zone habitats. Here it extends usually from the middle or end of May until the beginning or middle of April (Text-figs. 7 , nos. 4, 5; 9), but sometimes plants can be found bearing reproductive tissue during late April and early May (Text-fig. 7 , no. I). The percentage of plants bearing reproductive tissue is also much higher in these habitats from June to September than on exposed shores, although the period of maximum reproduction still occurs at the same time (Text-fig. 7, nos. I, 4 and 5).

The slower rate of casting of the distal frond tissue in the older plants in these habitats is partly responsible for the increase in the percentage reproduction during the summer and autumn months (Text-fig. 7, nos. I, 4); equally important, however, is the persistence of large numbers of summer and autumn sporophytes that start to bear reproductive tissue during the summer and autumn following their germination (Table VII; Text-figs. 7, no. $5 ; 9$ ), when they are approximately I year old.

In most populations of this species growing on the British coast reproductive tissue is not developed by the plants during late April and early May. Two factors are responsible for the absence of reproductive tissue during this period. In some populations, particularly in those growing on exposed shores, the distal frond tissue persisting on the plants during that period is not normally more than 5 months old and consequently it does not develop reproductive tissue (Text-figs. 7 , nos. 2, 3; 8A, B). In other populations, usually those growing on sheltered parts of the coast, although distal frond 
tissue in the sixth month of growth may be present on the plants during that period, it is still expanding (secondary growth above the $10 \mathrm{~cm}$. level) and therefore does not form reproductive tissue (Text-figs. 7 , nos. 4,$5 ; 9$ ).

The few plants of this species which do bear reproductive tissue during late April and early May have either retained distal frond tissue in the seventh month of growth, or have distal frond tissue in the sixth month of growth that has reached its full expansion and can therefore produce reproductive tissue.

As the peak of secondary growth above the $10 \mathrm{~cm}$. level occurs a month earlier on the Devon coast (February, March) than on the Argyll coast (March, April), there is a higher percentage of plants bearing reproductive tissue during late April and early May on the Devon coast, in habitats in which the plants can retain sufficiently old frond tissue to reach maturity (Text-fig. 7, cf. no. I with nos. 4 and 5).

From the above information on the reproductive cycles of populations of this species growing in different habitats it should be possible to estimate the approximate duration of the reproductive period in any population of L. saccharina growing on the British coast.

The data that have been accumulated during this work seem to indicate that the development of reproductive tissue in plants of this species is controlled by some factor or factors within the frond tissue of the plant, not by factors external to the plant. Van Overbeck (1940) extracted an auxin from a member of the Laminariales, Macrocystis pyrifera, and produced evidence to show that in this species the auxin was a growth hormone. It would be of interest if chemical changes, or an alteration in a hormonal balance, could be traced within the frond tissue of $L$. saccharina over a period of 6 months from the time of formation of the tissue until the tissue approaches maturity in the sixth month of growth.

\section{WEIGHT OF THE SPOROPHYTE}

In the literature there is very little information on the quantities of the different Laminaria species growing on the coastline of any country. From a Russian survey in July I93I (Meyer, I933) the stock of the Laminariales in the White Sea was estimated at $\mathrm{I}, 500,000$ metric tons.

At the same time Kireeva \& Schapova (1933) showed that, on the Murman coast in Kolsky Fjord and off Kildin Island, the average weight of a $L$. saccharina plant and of a $L$. saccharina population varied in different regions, the plant from I40 to $470 \mathrm{~g}$. and the population from 4.7 to $5.7 \mathrm{~kg}$. $/ \mathrm{m} .^{2}$

Tikhovskaya (1940), working on the seasonal variations in the productivity and photosynthesis of L. saccharina, calculated that the biomass of L. saccharina in the Dalne-Zelenety Bay of the Barents Sea amounts to 4000 metric tons $/ \mathrm{km} .{ }^{2}$ $\mathrm{He}$ found that in August the average weight of a $L$. saccharina plant was $613 \mathrm{~g}$. and that the weight of the L. saccharina population varied from 2 to $8 \mathrm{~kg} . / \mathrm{m} .{ }^{2}$, 
the weight of the population decreasing gradually towards the shore line from the level of $0.2 \mathrm{~m}$. (height of water level above 0 depth). He also states that with decrease in level below $0.2 \mathrm{~m}$. the plant size increased while the number decreased. The quantity of another species, L. japonica Aresch., growing on the coast of the Japanese Sea near Cape Povorotny is given by Gail (1935) as 4000 metric tons $/ \mathrm{km}^{2}$

In the last few years only has any estimation of the quantities of the Laminariales on the British coast been attempted. In I942 Chapman (I944) made a rapid survey for the Ministry of Supply of the quantities of the Laminariales growing round the coasts of England and Scotland. At the present time a detailed survey of the Laminaria resources of the Scottish coast is being made by the Scottish Seaweed Research Association. The results already published (Walker, 1947) show that the average growth of the Laminariales on the sublittoral areas so far surveyed around Orkney (Scapa Flow and Bay of Firth) amounts to just under 4000 metric tons $/ \mathrm{km} .{ }^{2}$ as against the estimated figure of $\mathrm{I} 400$ metric tons $/ \mathrm{km} .{ }^{2}$ for plant production in the English Channel down to $70 \mathrm{~m}$. (Atkins, I923).

\section{Maximum Weight}

A plant of $L$. saccharina growing on the British coast reaches its maximum weight at the end of the second period of rapid growth when the frond tissue of the plant shows the greatest length and width. Winter- and spring-developed plants are eight to fourteen times heavier at the end of the second period of rapid growth than at the end of the first period of rapid growth; plants developed later in the year, however, do not show such a great difference in weight at the end of the two growth periods owing to the greater growth-rate during the first period of rapid growth. Depending on the bathymetric zone, habitat and geographical position in which the species is growing, the maximum weight of a plant can vary from 0.12 to $2.5 \mathrm{~kg}$.

According to Yendo (I9I9) and Gail (1935) L. japonica and three other Japanese species also reach their maximum weight during the months of May and June in the second year of growth. They state, however, that these species perish after the second sporulation. Their life cycles are therefore similar to that of the L. saccharina plants growing in the intertidal zone on exposed parts of the British coast in habitats that dry out at low water of mean spring tides.

\section{SEASONAL Variation IN Weight}

On the British coast there is a seasonal variation in the weight of any L. saccharina plant (Text-fig. I0) whatever the age, bathymetric zone, habitat or latitude as there is in the frond size of the plant (Pls. V-VII, IX-XI). This seasonal variation in the weight of the sporophyte is also recorded by the 
Russian workers for the White Sea and the Barents Sea. Kireeva \& Schapova (1933, 1938) and Tikhovskaya (1940) show that on the Russian coast L. saccharina reaches its maximum weight in August and its minimum weight in March. On the British coast, however, L. saccharina reaches its maximum

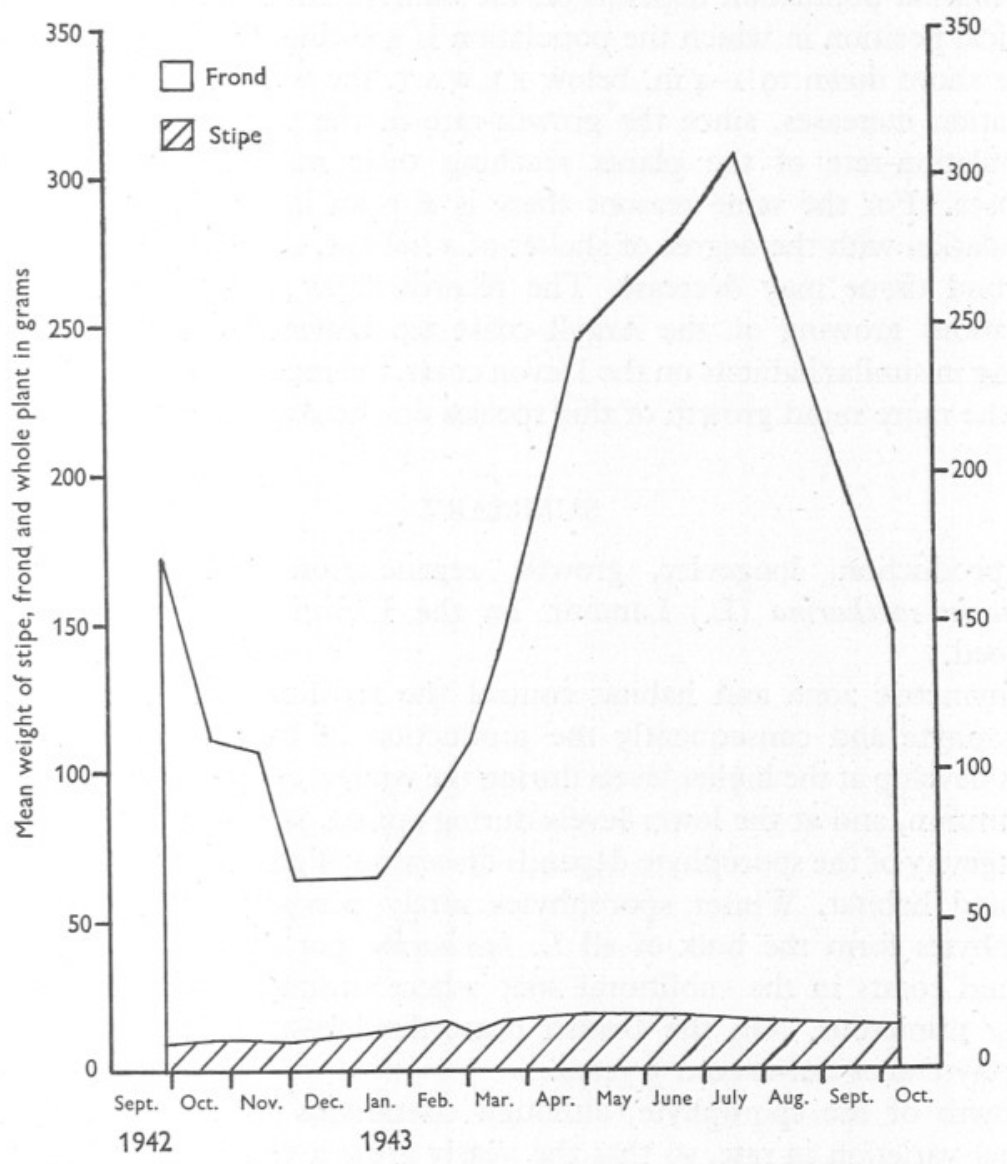

Text-fig. Io. Seasonal variation in the weight of $L$. saccharina plants growing on a raft in Plymouth Sound.

weight in June or July and its minimum weight in December or January (Text-fig. I0), that is, I-2 months earlier than on the Russian coast. On the British coast the maximum weight is four to six times greater than the minimum weight, whilst on the Russian coast the maximum weight is recorded as seven times greater than the minimum weight (Kireeva \& Schapova, 1938). 


\section{VARIATION IN Weight With Bathymetric ZoNe, Habitat AND GEOGRAPHICAL Position}

From the earlier sections of this paper it can be seen that the weight of any L. saccharina population depends on the bathymetric zone, habitat and geographical position in which the population is growing. With decrease in level on the shore down to I-4 m. below E.L.W.S.T. the weight of a $L$. saccharina population increases, since the growth-rate of the plants increases and the depopulation-rate of the plants reaching their maximum weight usually decreases. For the same reasons there is also an increase in the weight of a population with the degree of shelter of a habitat, although the thickness of the frond tissue may decrease. The records show also that $L$. saccharina populations growing on the Argyll coast are heavier than the populations growing in similar habitats on the Devon coast, the increase in weight resulting from the more rapid growth of this species on the Argyll coast.

\section{SUMMARY}

The production, longevity, growth, regeneration and reproduction of Laminaria saccharina (L.) Lamour. on the Devon and Argyll coasts are described.

Bathymetric zone and habitat control the fertility and longevity of the gametophyte and consequently the production of the sporophyte. Sporophytes develop at the higher levels during the winter, early spring, late summer and autumn, and at the lower levels during spring, summer and autumn.

Longevity of the sporophyte depends on season of germination, bathymetric zone and habitat. Winter sporophytes rarely persist to maturity. Spring sporophytes form the bulk of all $L$. saccharina populations except on very sheltered coasts in the sublittoral zone where summer sporophytes may be equally numerous. On the British coast the life-span of a $L$. saccharina sporophyte does not exceed 3 years.

Growth of the sporophyte, although continuous throughout life, shows seasonal variation in rate, so that the yearly growth can be divided into two periods, one of more rapid growth (January to June) and one of slower growth (July to December). Seasonal change in rate of frond growth is indicated by change in shape of the base and also by the variation in the width of the tissue produced. The rate of growth of the tissue at successive levels up the frond also shows a seasonal variation. Seasonal change in rate of stipe growth is indicated by alternate zones or 'rings' of lighter and darker tissue, the darker being formed during the periods of slow growth. The approximate age of the sporophyte can be assessed from an examination of the holdfast.

The growth-rate changes with the increase in the age of the sporophyte, the maximum rate being reached during the second period of rapid growth. The 
rate of growth also varies with change in bathymetric zone, habitat and latitude.

Distal frond tissue is cast continuously throughout the life of a sporophyte, the rate of casting varying with the time of germination and with the habitat. The normal age of the oldest frond tissue is from 5 to 7 months; 9-months-old frond tissue has not been recorded.

Complete regeneration of the frond after cutting occurs only in sporophytes up to the age of I year. No regeneration occurs when the whole frond is removed.

Sporophytes first reach maturity when they are from 8 to I 2 months old.

For reproductive tissue to develop on a plant the distal tissue present on the frond must be in at least the sixth month of growth. Once reproductive tissue is present on frond tissue in the sixth month of growth, it can arise on frond tissue in the fifth month of growth but not on younger frond tissue.

The percentage of reproducing plants and the duration of the reproductive period in a population depend on the numbers of different season and year groups making up the population and on the habitat in which it is growing.

The maximum weight of the sporophyte is reached at the end of the second period of rapid growth. The sporophyte shows a seasonal variation in weight and also a variation in weight with change in bathymetric zone, habitat and geographical position.

\section{REFERENCES}

Agardh, J. G., I867. De Laminarieis. Lunds Univ. Arsskr., Bd. 4, No. Io, pp. I-36. AtKINs, W. R. G., I923. The phosphate content of fresh and salt waters in its relationship to the growth of the algal plankton. Fourn. Mar. Biol. Assoc., Vol. xIII, pp. II9-50.

- 1939. Illumination in algal habitats. Bot. Notiser, I939, pp. 145-57. Lund.

BLACK, W. A. P., I948. Seasonal variation in chemical constitution of some common British Laminariales. Nature, Vol. I6I, p. I74.

Børgesen, F., I903. Marine Algae. Botany of the Faeröes, Pt. II, pp. 339-532. Copenhagen.

Chapman, V. J., I944. Methods of surveying Laminaria beds. Fourn. Mar. Biol. Assoc., Vol. xxvi, pp. 37-60.

Drew, G. H., I9I0. The reproduction and early development of Laminaria digitata and Laminaria saccharina. Ann. Bot. Lond., Vol. xxIv, pp. I77-90.

Fallis, A. L., I9I6. Growth of some Laminariaceae. Puget Sound Mar. Sta. Publ., Vol. I, No. I3, pp. I37-55.

FarLow, W. G., I882. The marine Algae of New England. Rep. U.S. Comm. Fish. for I879, Appendix A, pp. I-2 Io, Washington.

Flerov, B. C. \& Karsakoff, N. W., I932. Liste des algues de la Nouvelle Zemble. Trans. Oceanogr. Inst. Moscow, Bd. II, pp. 69-74.

FosLIe, M., I884. Ueber die Laminarien Norwegens. Forh. Vidensk. Selsk. Kristiania, No. I4, pp. I-II2.

- I890. Contributions to knowledge of the marine Algae of Norway. I. EastFinmarken. Tromso Mus. Aarsh., Bd. 13, pp. I-186. 
FreUndleR, P. \& MÉNAGER, Y., I92I. Recherches sur l'exploitation et l'utilisation industrielle des principales laminaires de côte Bretonne. Office Sci. et Techn. Pêches Maritimes, Paris. Notes et Mémoirs, No. 5, pp. I-3I.

Fritsch, F. E., I945. The Structure and Reproduction of the Algae. Vol. II, 939 pp. Cambridge.

GAIL, G. E., I935. On the question concerning the rationalisation of profit in the seaweed industry. Fishery Research of the Far East, Vol. XIII, pp. I09-I7, Vladivostock. (Title and paper in Russian.)

Guignard, L., I892. Observations sur l'appareil mucifère des Laminariacées. Ann. Sci. Nat., Bot., T. I5, pp. I-46.

HAAs, P. \& HILL, T. G., I933. Observations on the metabolism of certain seaweeds. Ann. Bot. Lond., Vol. xLVII, pp. 55-67.

HARRIES, R., 1932. An investigation by cultural methods of some of the factors influencing the development of the gametophytes and the early stages of the sporophyte of Laminaria digitata, L. saccharina and L. cloustoni. Ann. Bot. Lond., Vol. XLVI, pp. 893-928.

Killian, K., I9II. Beiträge zur Kenntnis der Laminarien. Z. Bot., Bd. 3, pp. 433-94.

KireEVA, M. S. \& Schapova, T. F., I933. Report on stationary works undertaken by the department of bottom algae for the State Oceanographical Institue for the study of iodine-bearing algae. Trans. Oceanogr. Inst. Moscow, Vol. III, No. 3, Pt. III, pp. 29-49. (English Summary.)

- 1938. Rates of growth, age and spore-bearing of Laminaria saccharina and L. digitata in Kola Fjord. Trans. Inst. Mar. Fish. Oceanogr. Moscow, Vol. viI, pp. 29-58. (English Summary.)

KJellman, F. R., I883. The Algae of the Arctic Sea. Svensk. Vet. Akad. Handl., Bd. 20 , No. 5, pp. I-350.

Knight, M. \& Parke, M., I93I. Manx Algae. Liverpool Mar. Biol. Comm. Mem. 30, I47 pages.

LE Jolis, A., I855. Examen des espèces confondues sous le nom de Laminaria digitata, suivi de quelques observations sur le genre Laminaria. Mém. Soc. Imp. Nat. Cherbourg, T. 3, pp. 24I-3I2.

MEYER, K. I., I933. Report of the work of the expedition for determining the stock of seaweed in the White Sea. Trans. Oceanogr. Inst. Moscow, Vol. III, No. 3, Pt. I, pp. 7-28. (English Summary.)

PRINTZ, H., I926. Die Algenvegetation des Trondhjemsfjorden. Skr. norske VidenskAkad., Mat.-Nat. Kl., No. 5, pp. I-273.

ReES, T. K., I928. The fruiting periods of the brown seaweeds. Proc. Swansea Sci. Fld. Nat. Soc., Vol. I, Pt. 2, pp. 33-7.

RUSSELL-WelLS, B., I932. Fats of brown seaweeds. Nature, I29, pp. 654-5.

Sauvageau, C., I9I8. Recherches sur les laminaires des côtes de France. Mém. Acad. Sci. Paris, T. 56, No. I, pp. I-240.

SCHREIBER, E., I930. Untersuchungen über Parthenogenesis, Geschlechtsbestimmung und Bastardierungsvermögen bei Laminarien. Planta, Bd. I2, pp. 33 I-53.

Schultz-Schultzenstein, I853. Ueber Schichtenbildung im Pflanzenreich mit Beziehung auf die natürliche Classification der Pflanzen. Flora, Bd. 36, 49 et seq., (reference pp. 70-3).

Setchell, W. A., I900. Critical notes on the New England species of Laminaria. Rhodora, Vol. 2, nos. I8, I9, pp. II5-I9, I42-9.

Stephenson, T. A. \& Dutort, C. A., I937. The South African intertidal zone and its relation to ocean currents. I. A temperate Indian Ocean shore. Trans. roy. Soc. S. Afr., Vol. xxiv, pp. 34I-82. Capetown. 
Stephenson, T. A., I939. The constitution of the intertidal fauna and flora of South Africa. Part I. Fourn. Linn. Soc. (Zool.), Vol. xL, No. 273, pp. 487-536.

TIKHovskaya, Z. P., I940. Seasonal variations in the productivity and photosynthesis of Laminaria saccharina in the Dalne-Zelenetz Bay of the Barents Sea. C.R. (DOKL.) Acad. Sci. U.R.S.S., Vol. xxix, No. 2, pp. I20-4.

van Overbeek, J., I940. Auxin in marine Algae. Plant Physiol., Vol. 15, pt. 2, pp. $29 \mathrm{I}-9$.

WALKER, F. T., I947. Sublittoral seaweed survey.-Parts I, II and III. Fourn. Ecol., Vol. 35, pp. I66-85.

WIMPENNY, R.S., I94I. Organic polarity: some ecological and physiological aspects. Quart. Rev. Biol., Vol. I6, No. 4, pp. 389-425.

Yendo, K., I919. A monograph of the genus Alaria. F. Coll. Sci. Tokyo, Vol. 43, pp. I-I45.

Zinova, E. S., I929. Algae maris japonensis (Phaeophyceae). Bull. Pacific Ocean Sci. Fish. Res. Sta., Vol. 3, Pt. 4, pp. I-62. Vladivostok. (French résumé.) 